
\title{
R Research Soure \\ Unsustainable Development: The Impact of Power Sector Reform on Policy Regimes in Sub-Saharan Africa
}

\section{Maxfield Peterson ( $\square$ mjp161@pitt.edu )}

University of Pittsburgh https://orcid.org/0000-0002-2023-4977

\section{Research Article}

Keywords: Public administration, political economy, energy policy, sustainable development, Sub-Saharan Africa

Posted Date: February 23rd, 2022

DOI: https://doi.org/10.21203/rs.3.rs-1304310/v1

License: (c) (i) This work is licensed under a Creative Commons Attribution 4.0 International License.

Read Full License 


\section{Introduction}

The countries of Sub-Saharan Africa lag behind those of every other world region in access to electricity (IEA, 2020), a critical element of infrastructure which has been shown to contribute to economic growth, education (Khandker et al., 2012), and female employment (Dinkelman, 2011). At the same time, Sub-Saharan Africa represents one of the greatest areas of opportunity for the development of renewable energy resources. Renewable energy technologies, particularly solar and wind, have not only become cost-competitive with traditional hydrocarbon alternatives, but are in many circumstances cheaper and more reliable sources of electricity generation. Yet almost everywhere on the continent, renewable energy represents less than $2 \%$ of electricity generation portfolios (IEA, 2020). Why is this the case? Scholars increasingly converge on the importance of "institutional quality" for understanding variations in development outcomes, but have thus far relied on an overly narrow yet opaque conceptual understanding of what this term means. Rather than defer to development bank ratings of "bureaucratic quality", this work explores how variations in policy regimes (the sets of institutions responsible for sector governance) both between countries and over time account for different development outcomes. This work finds that successive waves of externally imposed reform agendas have layered conflicting modes of governance on Sub-Saharan African power sectors, resulting in a form of internal inconsistency between institutional incentives and policy instruments that I call policy regime incoherence. Drawing on literature from public administration, political economy, and energy transition studies, this work proposes a model of policy regime coherence that explains how interactions between incumbent regime structures and novel reform agendas can create ambiguities of responsibility. These ambiguities permit institutional actors to selectively implement policy in ways that are more responsive to pathdependencies than new policy initiatives, specifically those attempting to spur renewable energy development.

The policy regime coherence model is tested through a mixed-methods approach. First the model is tested on a qualitative, longitudinal comparative case study of power sector reform in Ghana, Kenya, and South Africa. Analyzed together, the case studies illustrate three main points: 1) the countries studied made the most progress towards their power sector goals under centralized, state-led developmental policy regimes that maintained clear lines of accountability and responsibility between principals and agents 2) the layering of new institutional rules under a regional wave of liberalizing reforms created ambiguities of responsibility that enabled agents to shirk renewable energy goals 3) exploitation of these same ambiguities by new regime actors has strengthened the position of hydrocarbon energy. The model is then tested quantitatively using a new panel dataset on policy interventions in the power sectors of over twenty sub-Saharan African countries. The results of the panel regression models are consistent with theoretical expectations and case study findings on the impacts of liberal- 
ization reforms on policy implementation. Taken together, the qualitative and quantitative evidence suggests that state-led planning under coherent, relatively centralized policy regimes has positive impacts on electricity access and renewable energy growth, while liberalization has negative effects. These findings suggest that scholars should move away from the policy literature's persistent focus on reforming policy frameworks to attract private investment, and towards the study of variations in administrative and policy design that account for the increasingly recognized role of institutional quality in questions of development.

\subsection{Overview of Power Sector Reform}

The nations of sub-Saharan Africa have generally failed to expand electricity access at a rate sufficient to keep pace with population growth (IEA, 2020). They have also failed to develop renewable energy sources anywhere near their potential, despite the contribution such a development would make to solving the electricity access problem (REN21, 2018).

Since decolonization began in the 1960s, development of power sectors has been a central concern of both African national leaders and the international development institutions that have partnered with them. In the decades after independence, the power sectors of most Sub-Saharan African countries can be characterized as developmental (Johnson, 1982; Leftwich, 1995), featuring investments of state-capital in large generation projects such as hydroelectric dams and thermal power plants. This period saw substantial rates of power sector growth across the region, but this growth faltered in the 1980s alongside other development objectives as states wrestled with civil conflict, a collapse in the value of agricultural commodity exports, and external debt crises (Bates, 2012).

As the third wave of democratization occurred in Sub-Saharan Africa throughout the 1990s, a new round of development assistance offered countries financial support in exchange for commitments to implement a set of reforms designed to liberalize power sectors. However, Sub-Saharan African governments resisted many key elements of what has come to be known as the "standard reform model," and by 2005 implementation had stalled in most countries (Foster and Rana, 2020). The grafting of liberalizing reforms on top of the developmental power sector regimes that characterized the post-independence decades formed what is now referred to as the "hybrid model." (Gratwick and Eberhard, 2008) Power sectors grew only modestly in the period from the beginning of the standard reform model until convergence around the hybrid model in 2005, and development institutions acknowledged that the "one-size-fits-all" approach was unlikely to be fully implemented (Gratwick and Eberhard, 2008). Figure 2 below plots the extent of reform implementation against energy access outcomes. Reform implementation is measured using the Power Sector Reform Tracker from 


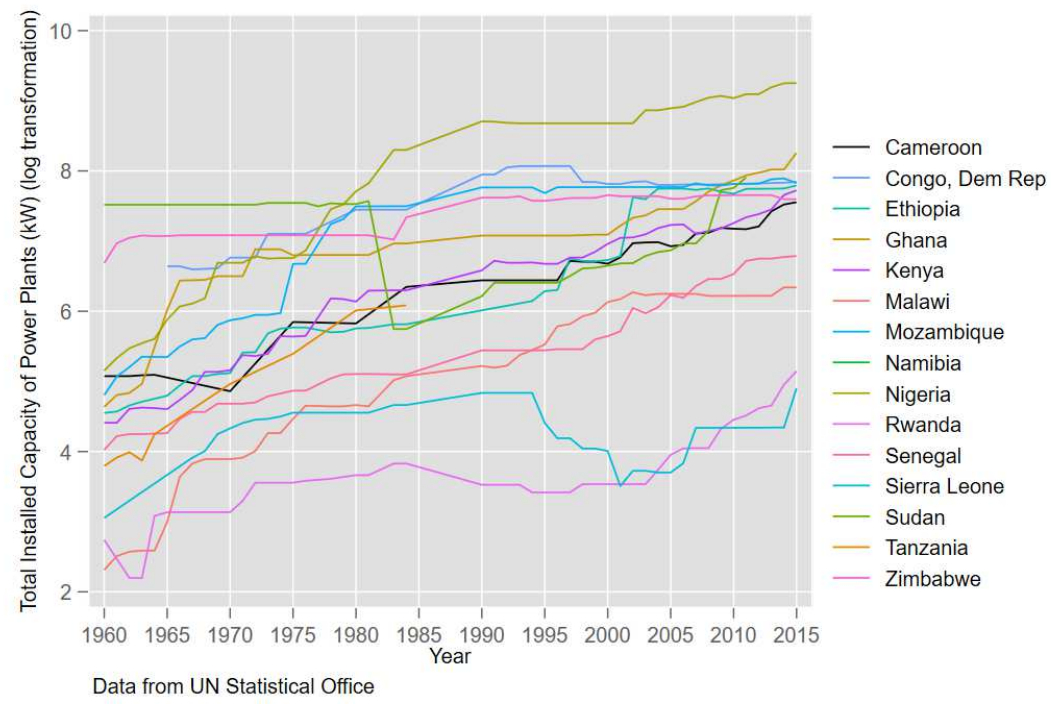

Figure 1: Electricity Production of a Sub-Sample of Sub-Saharan African Countries 1960-2015. Data from U.N. Statistical Division.

Urpelainen and Yang (2018), which documents privatization of state-owned enterprises, commercialization of consumer tariff prices, the opening of the market to private investment, and other key elements included in the Standard Reform Model $^{1}$. As can be seen, there is no obvious relationship between reform implementation and access to electricity. Ghana and South Africa stand out as exceptions to the general trend that in most countries, less than $2 / 3$ of the population has access to electricity. Both countries are also exceptions in that they have gone further than most others in implementing reforms. However, as the case studies will demonstrate, this is largely a product of these countries' choices to implement reforms after locking in strong state-led electrification programs.

In 2005 the G8 Finance Ministers agreed to try and accelerate progress towards the United Nations Millennium Development Goals (MDGs) by providing enough funds to the World Bank, IMF, and the African Development Bank to cancel 40 to 55 billion USD in debt for heavily indebted poor countries. This debt write-off allowed countries to divert resources from debt service towards the furtherance of the MDGs, and to apply for additional capital from international development institutions (IDIs). This coincided with an emerging emphasis in power sector reform centered around "sustainable development," which emphasized the promotion of policy frameworks to achieve universal electricity access and develop renewable energy resources (Elliot, 2012).

\footnotetext{
${ }^{1}$ The complete details of the Power Sector Reform Tracker can be found in the Data and Analyses section
} 


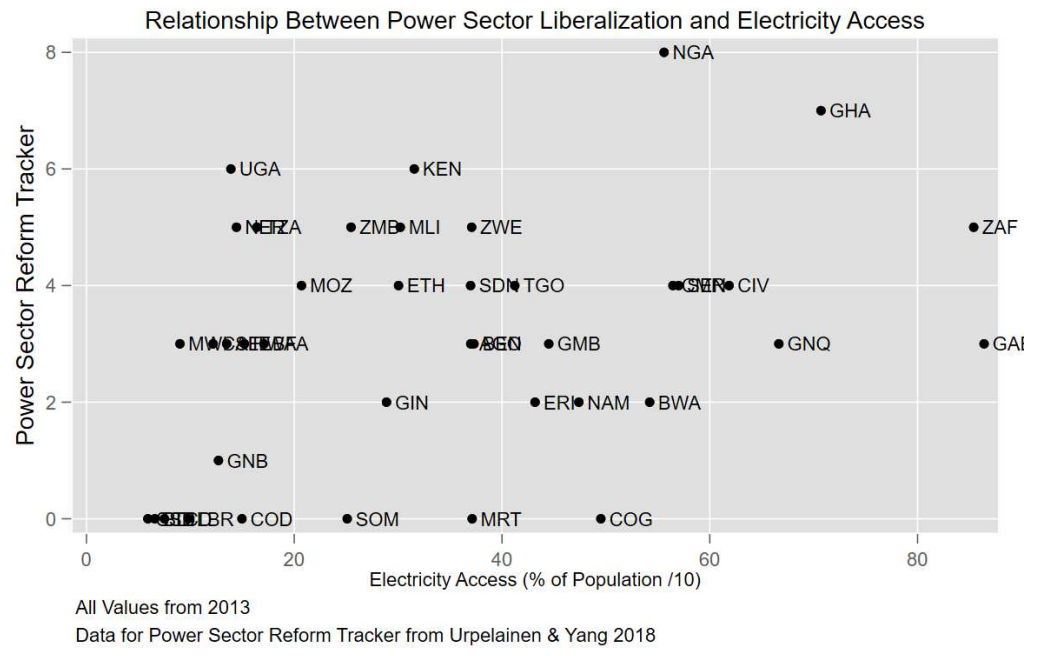

Figure 2: Relationship Between Power Sector Liberalization and Energy Access. Power Sector Reform Tracker from Urpelainen and Yang (2018)

While the sustainable development approach was openly committed to social development goals, it continued the standard reform model's reliance on commercialization and privatization as a means of attracting foreign investment, but also recommended supply-side incentives such as feed-in-tariffs designed to induce investment in renewable technologies (Foster and Rana, 2020) (Urpelainen and Yang, 2018). From 2005, power sectors resumed a pattern of growth in generation capacity, albeit at a less rapid pace than in the decades following independence (see figure 1). Despite these positive changes, progress towards the goals of electricity access and renewable energy growth has been sluggish across most of the region, with a few notable exceptions. Figure 3 below charts the relationship between implementation of regulations tracked by the World Bank's "Regulatory Indicators of Sustainable Energy," (RISE)(a marker of the Bank's approach to the sustainable development of power sectors, measurement of which is described in the Data section), and electricity generated from renewable sources as a percentage of total production. There is no clear relationship between implementation of these reforms and renewable energy production, although Kenya stands out for scoring well on both measures. As with Ghana and South Africa's gains in electricity access, the case study on Kenya reveals that this is a result of state-led programs in the Kenyan power sector that locked-in commitments to geothermal development decades prior to liberalization.

Why is power sector growth generally slower now than in the decades after independence? What separates countries which have been successful at promoting energy access or renewable energy development from those which have 


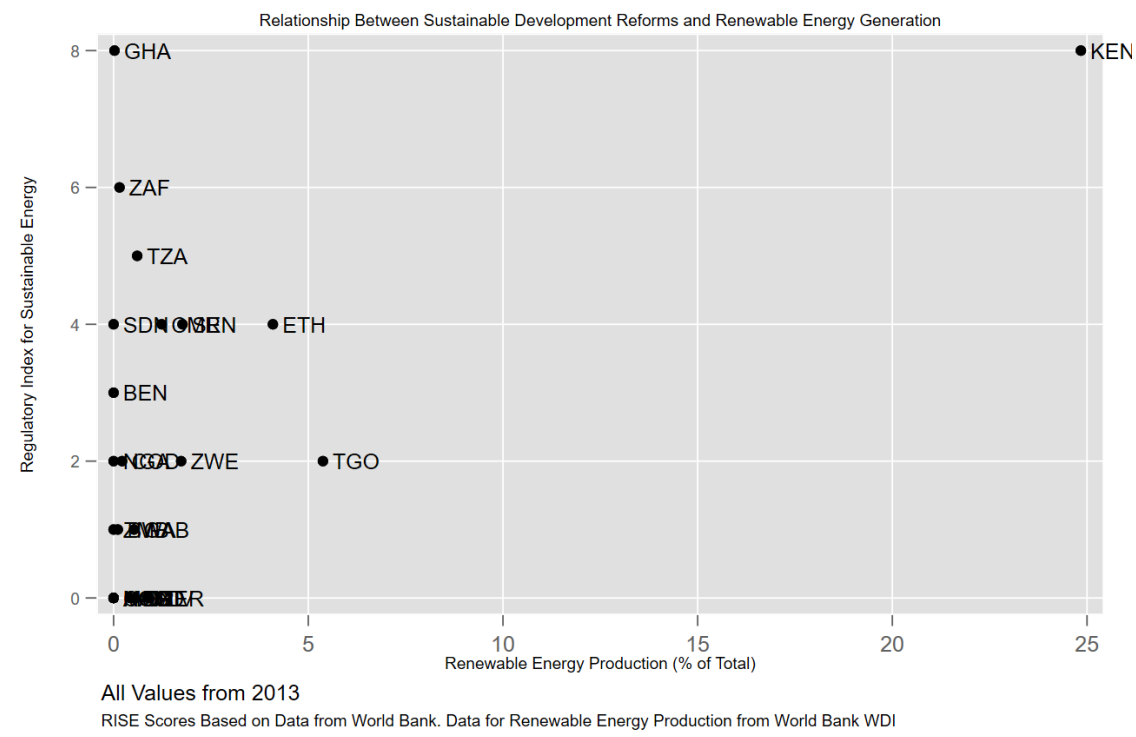

Figure 3: Relationship Between Sustainable Development Reforms and Renewable Energy Production

not? This study focuses on institutional explanations for differences in sector performance, but digs deeper than previous studies by exploring how variations in institutional design, both between countries and over time, account for differences in sector outcomes. This work proposes a model in which policy regimes, or the sets of actors and institutions responsible for sector governance, incorporate new policy goals by adapting incumbent institutions to accommodate new incentives, or layer new institutions on top of the existing regime. An evaluation of the model against three major cases illustrates that regimes which incorporate new goals into the incentive structures of incumbent institutions are more effective at implementation, while regimes which establish new institutions to accomplish new goals encounter bureaucratic competition, regime resistance, and ambiguities of responsibility that undercut effective implementation. Before outlining the model, I briefly review existing institutional explanations for the problems facing sustainable development.

\section{Literature Review}

The quality of institutions, such as bureaucratic effectiveness, rule of law, and the extent of corruption, are increasingly recognized as critical to economic development (Acemoglu and Robinson, 2012). Ahlborg, Borang, Jagers, and 
Söderholm (2015) find that institutional quality is positively correlated with household electricity consumption across a range of Sub-Saharan African countries, and use the World Bank's Worldwide Governance Indicators (WGI) for Rule of Law and Control of Corruption to measure institutional quality. While it is useful to know that well-performing bureaucracies, a lack of corruption, and strong rule of law are important for power sectors to grow and provide access to citizens, this is something of a truism. In places where bureaucracies work well, they work well at providing electricity access. What is important for both scholars and practitioners is understanding why and how bureaucracies work well.

In their global comparative study of energy poverty, Aklin et al. (2018) argue that institutional capacity, or "government's access to an administrative apparatus that is capable of implementing policies in a competent and cost-effective manner," is one of three required variables for extending electricity access to rural areas. Aklin et al. (2018) go farther than most analyses of institutional quality through a set of comparative case studies that usefully demonstrate how, even in the presence of representative democracy and strong government interest, institutional capacity is an essential ingredient for energy access. The authors also shed some light on what successful (Ghana) and unsuccessful (Kenya, Nigeria, Senegal) institutional apparati look like. In doing so, they have pointed the literature in a productive direction; while democracy, rule of law, a lack of corruption, and economic growth all enhance the possibilities for governments to make good on commitments to expand electricity access and develop renewable energy, they matter little if the institutional apparatus responsible for sector governance is not up to the task. What the authors do not do is present a systematic theory about what sorts of administrative structures and policy designs result in the institutional capacity required for government interest and local accountability to work together to deliver improvements in electricity generation, transmission, and distribution that satisfy demands for universal access. This work helps fill that gap by proposing an institutional theory that explains the success and failure of various policy regimes at accomplishing development goals.

\subsection{Power Sector Organization}

The question of how to structure power sectors to sustainably expand energy access has received increasing scholarly attention in recent years. This literature falls into two broad camps.

The first camp is characterized by a technical focus on creating conditions that lead to greater levels of investment in electricity generation. This approach assumes a limited role for the government in which its primary responsibility is to create conditions for the private sector to fulfill policy objectives. Gregory and 
Sovacool (2019) refer to this as the "Financial Investment Governance" (FIG) perspective, and it encompasses much of the literature attempting to explain the state of electricity access in Sub-Saharan Africa (Pueyo, 2018; Labordena et al., 2017; Collier and Venables, 2017). The primary contribution of this literature has been to identify key policy barriers to private capital investment in electricity generation such as subcommercial consumer tariffs, state-owned enterprise monopolies, local content requirements, and exchange rate convertibility (see Gregory and Sovacool (2019) for a full review of the diagnosis).

There are two problems with FIG literature: the first is its unjustified ex ante assumption that attracting private sector generation is either necessary or sufficient to solve countries' electricity access and renewable energy development problems. As Aklin et al. (2018) and this analysis will show, much of the historical and recent progress on extending electricity access has come through a combination of ambitious investments of state capital and long-term planning rather than from private sector participation. The second problem of this approach is that it offers limited, ad hoc accounts of the political and economic reasons for why the policy inefficiencies it identifies persist. As Baker et al. (2014) and Lawhon and Murphy (2011) put it, "a more narrow focus on policy management characterises much of the literature reflecting a "tendency towards techno-economic determinism' amongst practitioners of the approach." Indeed, as Baker further notes, this literature's endemic focus on identifying technically deficient policy frameworks led Meadowcroft to call for politics-oriented literature on sustainability transitions because "behind policy there is always politics" (2011). Aklin and Urpelainen (2018) similarly note that this literature's line of inquiry "focuses on techno-economic considerations and treats policies and politics as an explanatory factor of secondary importance," (p. 15-16).

A second camp views power sectors as embedded within political and economic processes that constrain and enable sector reform and policy outcomes, and explores questions about how combinations of change in contextual factors as well as sectoral reforms can lead to greater electricity supply, universal electricity access, and renewable energy development. This camp has been historically segregated into three strands of literature, one focused on "socio-technical systems," one focused on policy regimes, and the third influenced by political economy and focused on interest group competition.

The socio-technical systems (STS) approach draws more heavily from sociology, technology studies, and policy science literature, and focuses on how large technical systems, such as national energy systems, are "deeply embedded in the overall structure of society," (Van de Graad et al., 2016)(16). STS has been methodologically associated with the "multi-level perspective" (MLP), which distinguishes three levels of analysis for understanding technical transitions: niche-innovations, sociotechnical regimes, and sociotechnical landscapes (Rip and Kemp (1998) Geels (2002) Geels (2011)Geels and Schot (2007)). The MLP has been generative for transitions studies, leading to many case studies of re- 
newable energy technology adaptation (see Genus and Coles (2008) for a thorough accounting of this literature and the analytical development of the MLP). However, the MLP has faced criticism for its lack of actor agency, operationalization of regimes, and its failure to transcend descriptive analyses Geels and Schot (2007). However, the MLP has been useful in providing an analytic focus on how the sets of institutions responsible for energy governance (sociotechnical regimes) interact with policy change and new technology. More recently, Andrews-Speed (2016) argues that rational-choice and historical institutionalism offer complementary frameworks to the socio-technical school by providing theories of institutional change. Cherp et al. (2017) attempt to integrate the socio-technical and political perspectives, arguing that economic development, technological innovation, and policy change are all prominent factors shaping energy transitions, and thus explaining energy transitions must draw from disciplines investigating all of them.

The policy regime perspective connects with the STS school in using regimes as the unit of analysis, but its conceptual foundation is in the public administration and governance literatures. This work analyzes how regimes make policy, and how incumbent regime elements interact with new policy goals and approaches. Howlett (2009) proposes a three-level nested model of policy instrument selection that offers a conceptual and methodological approach for understanding how governance arrangements (ideas and interests at the highest level of policymaking) and modes of governance (market, corporatist, network) constrain choices for policy approaches at the regime level (the sets of institutions responsible for setting policy) and for instrument selection at the implementation level. Howlett and Rayner (2007) contribute to this model by theorizing about how regime changes over time can lead to incoherence, or inconsistencies between goals and policy instruments. Kern and Howlett (2009) apply this model to understanding how policy legacies impact coherence with new policy approaches to Dutch energy transition management. The authors make an important innovation by applying conceptual tools from the new institutionalism for understanding institutional change to their understanding of policy regime incoherence, specifically the mechanisms of layering, drift, replacement, and conversion as theorized in Mahoney and Thelen (2010).

While not focused on energy issues, May and Jochim (2013) provide a rich theoretical account of the "policy regime perspective" and apply it to understanding policy feedback. They argue that understanding the back-and-forth between policy making and policy feedback necessitates a conceptual focus on "policy regimes, or "the governing arrangements for addressing policy problems." (May, 2015). In this context, the authors clarify that "governing arrangements can be broadly construed to include authoritative actions (executive orders, statues, rules), institutional arrangements, and interest alignments, and shared ideas," (3). Further, the authors note that "as with other constructs in the policy literature... one does not directly observe a policy regime. Instead, one observes its components. These are the ideas, institutional arrangements, and interest 
alignments that constitute a given policy regime." (3). A key insight is that public policy outcomes result in political responses that shape the environment in which public policy gets made. This feedback can thus ultimately impact the regime itself, and can do so in ways that can be advantageous or adverse to the initial political goals. In the case that such feedback is negative, the impact to the policy regime is dependent on its "strength," or the "the degree to which a regime reinforces the political commitments made by policymakers in addressing a given problem." Strength is determined by policy legitimacy ("acceptance by the governed of the goals and approach for resolving problems"), policy coherence ("the consistency of actions in addressing a given set of policy problems of target groups"), and policy durability (the sustainability of political commitments over time). (2012).

The third strand of literature is more actor than system oriented and focuses on competition between political-economic interest coalitions in the energy policymaking and implementation process. Stefes and Laird (2010) conduct a comparative institutional analysis of the distinct trajectories of renewable energy development in Germany and the United States. The authors argue that the oil crisis of the late 1970s resulted in a punctuated equilibrium Baumgartner and Jones (1993) of both nation's hydrocarbon economies, and motivated policy entrepreneurs in both countries to push for alternative sources of energy. Urry's 2011 concept of "carbon capital," proposes that historical configurations of economic, political, cultural, and military dimensions of power contribute to a "lock-in" of political economic arrangements around fossil fuels. Aklin and Urpelainen argue that political competition augments the policy impact of external shocks and market failures, and that governments strategically leverage path-dependency for political gain. Building on Fine and Rustomjee's 1996 study of South Africa's "minerals-energy complex," Baker et al. (2014) and Baker and Sovacool (2017) explore political-economic competition in financing structures for renewable energy in South Africa.

\section{Theory}

The STS, policy regime, and political economy perspectives all make crucial additions to our understanding of the power sector problems facing Sub-Saharan African countries. STS draws analytic focus to the sets of institutions that act as gatekeepers for new energy technologies, the policy regime perspective offers strong conceptual tools for understanding how these regimes function and change, and the political economy perspective helps us understand how interestgroup competition places pressures on those regimes and shapes policymaking approaches. What is now needed is an integrated theoretical approach that reconciles these disparate literatures to provide an effective method of understanding policy success and policy failure in the energy domain. 
This work proposes a model of policy regime coherence in order to understand how administrative structure and policy design relate to effective implementation. Perfectly coherent policy regimes are those in which institutional ideas, interests, and incentives are fully aligned up and down the structure of the policy regime. Coherent regimes are highly effective at implementing policy because the roles and responsibilities of actors and the policy instruments they choose are synergistic, and thus all actors working towards their own interests creates net benefits towards policy goals. Incoherent regimes are ineffective at implementing policy because their roles and policy instruments are antagonistic, and thus all actors working towards their own interests create net losses.

Policy regime coherence is inversely related to coordination costs. Coordination costs are the expenses of interest (in influence, political and monetary capital, communication and information-sharing) that institutions must incur to effectively implement policy. Highly coherent regimes have low coordination costs because policy can be implemented effectively simply by institutional actors maximizing their own interests. Incoherent regimes have high coordination costs because institutions must make sacrifices to effectively cooperate in order to implement policy.

We now turn to a focus on the theoretical structure of policy regimes, so as to identify what variations in features can lead to lower/higher coordination costs, higher/lower coherence, and thus higher/lower policy effectiveness.

\section{Governance Arrangements Level}

At the top of policy regimes in the governance arrangements level. This is the set of elected officials responsible for setting overarching policy goals such as industrialization, universal electricity access, or renewable energy development. It is also a level at which the variables emphasized by the political economy approach come into play. Actors at the governance arrangements level are motivated by a combination of ideas and interests. Ideas may refer to ideological commitments (such as a socialism, capitalism, or nationalism) as well as preferences for governance styles (statist, market, corporatist). Interests reflect the set of incentives constituted both by ideological commitments but also by practical demands to respond to political and economic pressures, such as the interest coalitions described by the political-economy perspective. Actors at the governance arrangements level may feel obligated to satisfy industry groups, international development institutions, mass publics, or networks of patron-client relationships that cement their place in power. They also operate as principals in the regime: they control direct legal and financial power over agents lower down in the state apparatus responsible for meso-level policy decisions and implementation. They may also influence non-state actors such as private corporations and unions, but this is less easily conceptualized as a principalagent relationship as these influences may work both ways depending on the power of non-state actors vis-a-vis those in government. 
This work adds a necessary complication to Howlett's nested model of policy instruments selection Howlett (2009). Whereas Howlett's model assumes a single mode of governance at the governance arrangements level, this model admits that multiple modes of governance may coexist within a single policy regime, being appropriated to different policy goals. For example, the implementation of goal X may follow a corporatist mode, while goal Y's implementation may follow a market governance structure. Delegation of a goal's implementation to a particular mode of governance may reflect the goal's importance to actors at the governance arrangements level, the costs the state is willing to assume on behalf of the goals implementation, or beliefs about effectiveness of different instruments (i.e. state vs. market).

\section{Policy Formation Level}

Directly below the government arrangements level is the policy formation level. The policy formation level is generally comprised of one or more cabinet-level government ministries that function as agents responsible for formulating and financing policy that responds to the ideas and interests of the governance arrangements level. Because the leadership of this group is generally appointed by actors at the governance arrangements level, it tends to mirror the same ideas and interests of those actors. However, different ministries may have different ideas, interests, and priorities. For example, conflicts may emerge between ministries responsible for financing programs and ministries responsible for implementing them. In the policy nexus of energy, power, and environment, three interdependent ministries may exist with interdependent portfolios but conflicting ideas, interests, and incentives.

\section{Implementation Level}

Beneath the policy formation level is the implementation level, which is responsible for the execution of policies set at the policy formation level. Depending on the governance preferences of the government arrangements level, there may be one or two distinct groups of actors at the implementation level.

Government Agent-Implementers: The first group of actors are government agent-implementers: agencies, regulators, state-owned enterprises, and other government entities such as "special-purpose vehicles" designed to fulfill specific policy objectives set at the policy formation level. This group is composed entirely of agents who are legally and financially responsible to principals at the policy formation level. Crucially, depending on governance modes preferred at the governance arrangements level and through the policy formation level, these agents may have varying levels of institutional strength and autonomy. In some cases, strength and autonomy may be so great as to render these institutions coequal to actors at the policy formation level and thus in a direct principalagent relationship with the governance arrangements level. Government-agent implementers will often be codependent upon one another to implement policy. 
Non-State Implementers: A second group of actors at the implementation level may exist when the state is not entirely responsible for implementation. These include private corporations and NGOs whose cooperation may be necessary for effective implementation of policies set at the policy formation level. These actors are distinguished from the first group in that they are not agents of the government. While they may act in cooperation with government, they are not always legally or financially obligated to implement government policy (although they may be forced to operate within its constraints). This means that they may operate in ways inconsistent with or unrelated to the ideas and interests of the governance arrangements level.

While the model thus far has been unidimensional, there is a dimension of actors outside the principal-agent structures that tie the governance arrangements, policy formation, and implementation levels together. These are political and economic actors outside of government who are affected by and have interests in the policymaking process. They are instrumental in policy feedback effects. When the government makes and implements a policy, they are affected. If this effect is positive, they may act across levels of the regime to entrench the policy. If this effect is negative, they may act across levels of the regime to frustrate or reverse the policy. This includes mass publics, political parties, labor unions, industry groups, as well as the second group of non-state implementing actors.

\section{Relationship To Coordination Costs and Coherence:}

Figure 4 above illustrates the policy regime coherence model and its relationship to coordination costs and coherence. The level of coordination costs and coherence vary along vertical and horizontal regime axes. Vertical coherence/incoherence means ideas and interests are aligned/misaligned up and down the policy regime, from the governance arrangements level to the implementation level. Low/high vertical coordination costs imply minimal/maximal costs to interests from cooperation between the three regime levels. Horizontal coherence/incoherence implies a strong alignment of ideas and interests within each regime level. Low/high horizontal coordination costs imply minimal/maximal costs to interests from cooperation between actors within each regime. Each institution is presumed to carry its own ideas and interests, and the extent to which these differ from one another contributes positively to regime incoherence. Non-state actors may operate along each level of the regime, and thus their alignment/nonalignment with the ideas and interests of each level and the extent to which each level depends on them for implementation raises or lowers the coherence and coordination costs of each level.

\section{Dynamic Effects}

Material, economic, political, changes impact institutions and their relations with one another, thus affecting coordination costs and coherence. Mahoney and Thelen (2010) specify four modes of institutional change: 1) Displacement: 


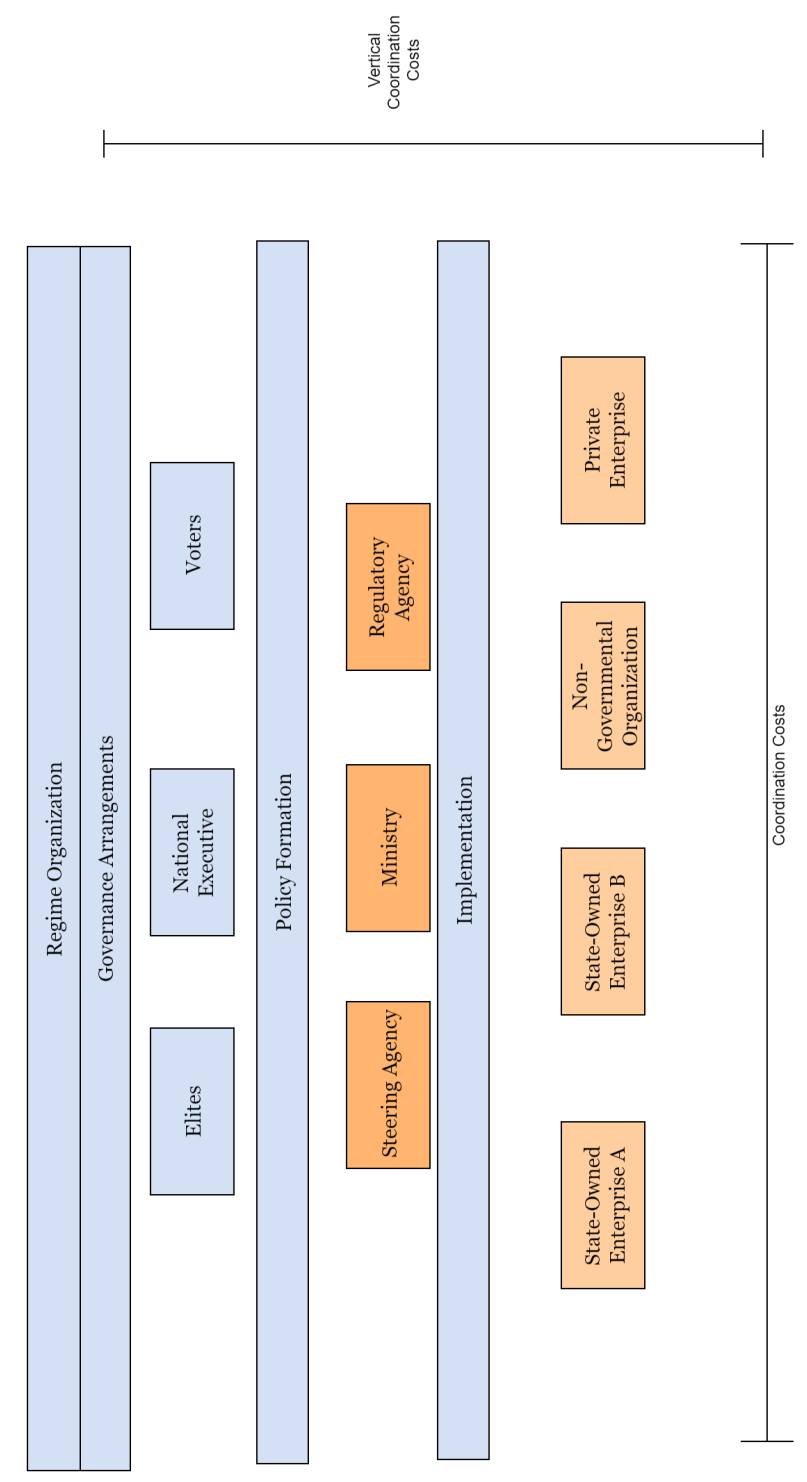

Figure 4: Model of Regime Coherence 
the removal of existing rules and the introduction of new ones 2) Layering: the introduction of new rules on top of or alongside existing ones 3) Drift: the changed impact of existing rules due to shifts in the environment 4) Conversion: the changed enactment of existing rules due to their strategic redeployment. The mode of institutional change that occurs is defined by an interaction of the veto possibilities in the current political context and the characteristics of the targeted institution. Importantly, these processes of change can create spaces of ambiguity in policy responsibility. When the rules governing an institution are altered to exclude a previous responsibility, and this responsibility is not clearly delegated to another institution, ambiguity of responsibility is created. Ambiguity can be ignored, leading to incoherence. However, ambiguity can also be exploited. Depending on the actor and their motivations for exploiting the ambiguity this may lead to greater coherence or incoherence.

\section{Comparative Case Study}

This comparative case study applies the model of policy regime coherence to three power sectors in Sub-Saharan Africa: Ghana, Kenya, and South Africa. The model examines how variations in regime structure, augmented through the dynamic effects of waves of power sector reform, have produced different levels of regime coherence, amounting to variations in success at pursuing sequenced policy goals of industrialization, universal electricity access, and renewable energy development. Purely in the interests of available space, a more detailed case study of Ghana is undertaken, with more limited reviews of Kenya and South Africa.

The cases are selected on the basis of Mill's Most Similar Systems (MSS) design. MSS selects cases on the basis of similarities in control variables, and differences in independent variables. The selection of Ghana, Kenya, and South Africa controls for the following variables: regional (they are all in Sub-Saharan Africa), democratic (the countries were all part of the third wave of democratization, and transitioned from various forms of authoritarianism to multi-party democracies over the course of the 1990s), Anglophone, Western bloc (with the exception of Ghana in the immediate years after independence, all three countries have been more aligned with Western powers than the Soviet-bloc), and period of independence (all three countries became independent from Britain in the period from 1959-1963).

The countries vary in the independent variable (policy regime structure) crosssectionally and over time. Each country had similarities in the developmental regime period, but with somewhat different goals. Each country experienced similar external pressures to reform their power sectors, but implemented different reforms at different times, under different circumstances, and to different ends. 
The countries also differ markedly in their energy resource endowments, especially in the period following independence prior to the discovery of additional resources or the advent of new technologies, each of which reflect government policy choices and are thus captured by variation in the regime variable. Each country roughly represents a distinct class of Sub-Saharan African energy economy; Ghana is richly endowed with hydropower resources, South Africa has abundant hydrocarbon resources (coal), and Kenya has few traditional energy resources and has historically relied heavily on imports to meet its electricity demand.

Data for the case studies was compiled through an exhaustive review of International Bank for Reconstruction and Development (IBRD)/ World Bank Reports, academic and journalistic accounts, and official reports and legislation issued by the governments under study.

\subsection{Ghana}

Institutional change in Ghana's power sector illustrates the implementation effectiveness of centralized administrative organization with limited agents and clear vertical accountability as compared with more decentralized alternatives. Ghana's developmental power sector policy regime, which lasted in continuous form from independence until 2005, made substantial progress first in developing electricity generation capacity and then in expanding electricity access Aklin et al. (2018). Robust implementation of liberalization reforms in 2005 created a decentralized "hybrid" regime by a) multiplying the number of principals responsible for implementation b) splitting responsibility for expanding generation capacity between state and market actors. The incorporation of renewable energy generation as a policy goal occurred under the hybrid regime. Unlike goals from the developmental regime, its implementation was assigned to a mode of market governance, for which a set of institutions and marketbased policy instruments (MBIs) were layered on top of the incumbent regime. Because implementation of MBIs required cooperation from legacy elements of the developmental regime that retained commitments to developmental regime goals and governing logics, renewable energy development has largely failed in Ghana. This study serves as a contrast to the Kenyan case, in which the goal of renewable energy development was incorporated into the developmental regime and thus benefitted from the same centralized administrative organization as the goal of universal electricity access did in Ghana.

\section{The Developmental Regime}

Ghana's developmental power sector policy regime was built around a centralized institutional core of tightly interwoven domestic actors. At the government arrangements level was the presidency and international development partners, the International Bank for Reconstruction and Development/World Bank, the 
United States Agency for International Development, and the Kaiser Aluminum Company (which entered into a joint aluminum venture with the Government of Ghana known as VALCO that would instrumental in the construction of the Volta River Dam). At the policymaking level were the Ministries of Energy and Finance. At the implementation level was the Electricity Company of Ghana (ECG), and the Volta River Authority (VRA) (International Bank for Reconstruction and Development, 1968).

The developmental regime was centered around a policy goal of industrialization for economic development (International Bank for Reconstruction and Development, 1968). The regime leveraged large combinations of state-capital and foreign developmental assistance to build major power sector infrastructure such as the Volta River Hydroelectric Project (Miescher, 2014)(International Bank for Reconstruction and Development, 1968). This period oversaw significant expansions in the country's total installed capacity, from 103.2 thousand $\mathrm{Kw}$ in 1960 to 900 thousand $\mathrm{Kw}$ in 1980 (see figure below). This growth in capacity was primarily leveraged to support large scale industrial operations in smelting and mining, as well as electricity access for residents of urban centers. Both the government and IBRD financing partners shared the view that extension into rural areas was important, but meeting the demands of rapid growth in urban centers was seen both as a priority and a more economic expenditure (IBRD 1970) (World Bank).

The coherence and relatively low coordination costs of the developmental era regime are evidenced by its continuity in institutional design and operation following a 1966 coup d'etat. The coup, widely seen as the result of a confluence of domestic actors opposed to the increasingly authoritarian Nkrumah presidency and Western powers opposed to Nkrumah's flirtations with the Soviet bloc (Miescher, 2014), did not appear to impact the overarching ideas, interests, or organizational characteristics of the power sector.At the governance arrangements level, national executives continued to see the power sector as instrumental to the country's economic progress, which was still seen as dependent on rapid industrialization. While the IBRD had always maintained reservations about the sustainability of Nkrumah's proliferation of state enterprises, they did not view the power sector as an unproductive area for public investment, but rather shared the domestic view that expanding electricity supply could lead to greater productivity in areas of comparative advantage such as mining, smelting, and agriculture (International Bank for Reconstruction and Development, 1970). Further, while the institutions responsible for implementation had been divided into two tightly interconnected, vertically-integrated organizations (ECG and the VRA), not only was the bank not recommending further decentralization, but it was actually in active talks with the government about the organizational benefits of merging the two organizations (International Bank for Reconstruction and Development, 1970)). 


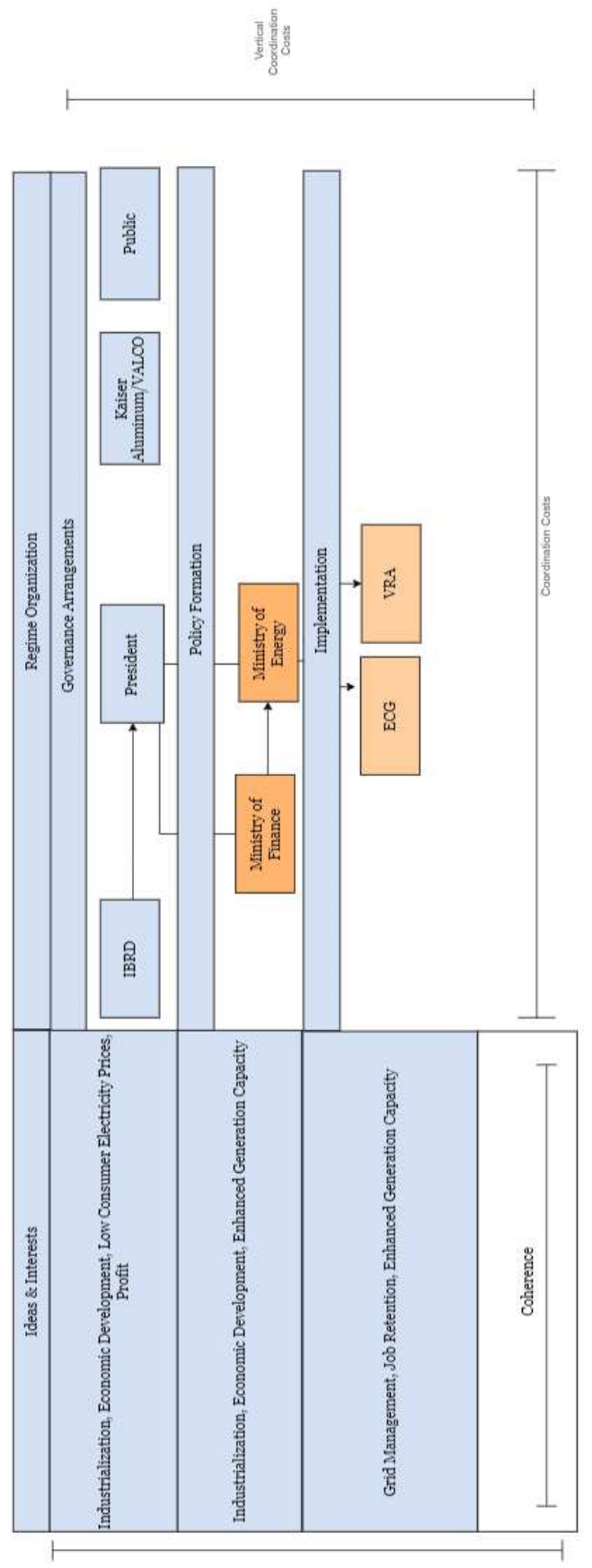

Figure 5: Ghana's Developmental Policy Regime 


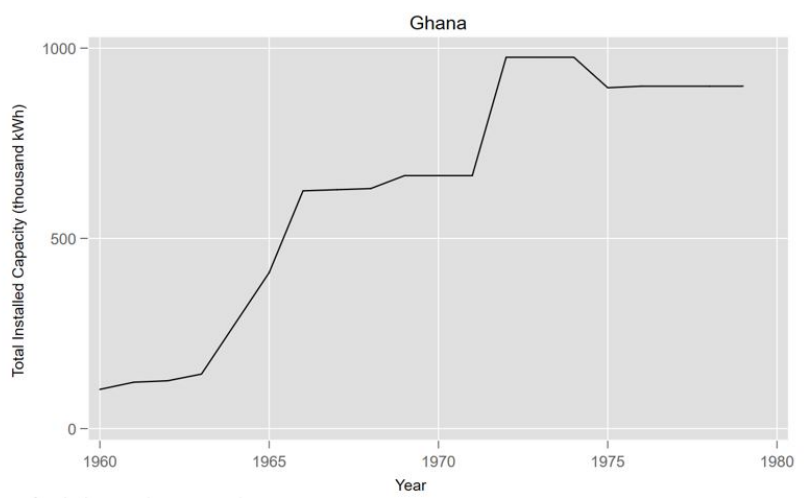

Figure 6: Electricity Production Growth in Ghana 1960-1980

\section{The Return of Electoral Democracy and the Incorporation of Univer- sal Electricity Access}

The period of political instability came to an end in 1979 with the military coup that placed John Jerry Rawlings in power. In 1989 the Rawlings' regime set in place a policy framework known as the National Electrification Scheme (NES) that would lead to the most significant expansion in electricity access that had yet occurred in the nation's history.

Established in the years leading to Ghana's first democratic election since Rawling's rise to power, the NES set a goal of universal electricity access by 2020 (Kemausuor and Ackom, 2017). The NES reflected a change in the ideas and interests at the governance arrangements level of the Ghanian power sector policy regime. The idea at the core of the developmental regime had historically been industrialization for economic growth. While industrialization continued to occupy a central role in the power sector regime, Rawlings' political prerogative to extend public benefits into the long-neglected northern regions of the country meant that the power sector would now accommodate a new policy goal of universal energy access. Crucially, rather than reform the institutional apparatus in order to accommodate this new interest, Rawlings retained the regime structure. Beginning in 1990, Ghana's electricity access began a rapid acceleration that would continue for three decades.

Incorporating the policy goal of extending electricity access did not appear to stretch the capacities of the developmental regime. The NES was designed so as to inlay the expansion of electricity access into the organizational fabric of the developmental regime by assigning the responsibility of grid extension and management to the same limited set of actors (the MoE, ECG, and the VRA) rather than establishing new institutions or policy mechanisms. This held coordination costs constant, and layered no new rules or ambiguities on the regime. 
A World Bank evaluation report of the Northern Grid Extension Project speaks to the effectiveness of the developmental regime's implementation of the NES: "the project was well prepared and implemented with commendable efficiency. The facilities included in the original scope of the project were completed below budget and on schedule," (World Bank, 1993) Similar to historical generation projects, the core of financing for the expansion came from direct investments by the GoG (with assistance from the World Bank), invested through the MoE, which laid and executed plan for grid extension. ECG continued to assume operation of any extensions to the grid, receiving proportionate appropriations to cover costs from the MoE. The large baseload of installed generation capacity that the regime developed over previous decades provided sufficient resources to support the expansion of the grid for the first ten years of the program, a period which oversaw the electrification of 2350 communities (approximately $56 \%$ of the original 4200 targeted communities) (Kemausuor and Ackom, 2017).

\section{Partial Liberalization and Regime Resistance}

The calls for power sector liberalization beginning the mid-90s were initially met with resistance from the Rawlings government. Already set upon an aggressive path to national electrification, unbundling and/or privatizing transmission and distribution would have represented an interruption to the state-led regime's operations. However, a drought in 1993 led to sweeping power cuts across the country, exposing the liabilities of the country's overreliance on hydroelectricity. In a bid to diversify the sector, the GoG sought support from the World Bank for the construction of a thermal power plant. The Bank offered financing in exchange for liberalization of the power sector (Gore et al., 2019). The Ghanaian government's response to this condition was a strategy of outward placation and internal regime resistance that delayed the implementation of the most significant reforms until 2005.

The GoG began by establishing the Power Sector Reform Committee (PSRC), which would study and make recommendations about how to reform the sector. The Bank took this as a sufficient commitment to reform and issued a $\$ 175.6$ million loan for the thermal plant and Takoradi, construction of which began under the extant state-led regime model. Three years later, the PSRC issued a plan that would 1) establish an independent regulator, 2) unbundle the Volta River Authority to allow competition in generation and distribution, 3) corporatize state-owned entities, and 4) make tariff-setting procedures more transparent. While the reform recommendations represented the consensus at the Bank, their implementation encountered significant resistance that led to long-term delays. The privatization of the VRA was opposed by VALCO, which feared the elimination of the aluminum company's long-term bulk electricity contract that was a cornerstone of the developmental regime's program of industrialization. VALCOs' protests delayed the privatization of the VRA for nearly a decade. The Ministry of Mines and Energy's attempt to raise tariffs approximately $300 \%$ was met by swift resistance from civil society, which held 
ongoing protests which successfully appealed to the Rawlings' administration to halt the increase. The administration did establish the Public Utilities Regulatory Commission (PURC), which it tasked with establishing tariff-setting guidelines. And while the PURC moderately raised tariffs in 1998, the institution has never maintained a policy of setting cost-reflective tariffs (Gore et al., 2019). Throughout the 1990s, amidst these pressures to reform, the developmental elements of the power sector policy regime continued to implement the NES, with the MoE, ECG, and VRA working together to extend distribution and transmission.

\section{The Layering of Market Governance}

Some aspects of the liberalization era reforms proved less controversial than tariff increases, unbundling, and privatization. Parliament passed legislation opening the sector to private investment and establishing the Energy Commission (EC), a "steering agency" which would serve as the regulator of private sector activity as well as provide recommendations to the President on directions for energy policy. While the EC received government appropriations as a statutory entity, it's finances also depended on levies on private sector activity in the energy and power sectors (Government of Ghana, 1997). The institutional incentives of the EC were thus aligned with their statutory mission; to increase private sector activity in the energy and power sector.

In 2000, the EC granted the first license to an IPP for electricity generation. While they were never fully privatized, ECG and the VRA were corporatized in 2000, and set under the direction of independent boards of directors. However, management continued to be appointed and controlled by the President (Gore 2019).

In December of 2000 John Kufour was elected president of Ghana, defeating JJ Rawling's Vice-President and NDC nominee John Atta Mills, marking the first transfer of executive office since Rawlings' forcefully took power in 1979. By the early 2000s, rapid growth in electricity demand from a combination of population growth, steady economic development, and the regime's ongoing implementation of the NES began to outstrip growth in generation capacity. Kufour did not stall the NES grid expansion despite its upward pressure on demand, and retained the developmental regime elements organized around its implementation (the MoE and ECG acting with the president's political sponsorship)(Kemausuor and Ackom, 2017). However, in order to meet growth in demand, Kufour decided to pursue reforms consistent with bank recommendations designed to incentivize investment in generation capacity by liberalizing the sector.

Under the Kufour administration, the government unbundled the VRA, multiplying the agents responsible for the implementation of policy, and the newly established Energy Commission issued guidelines for private sector generation 
investment, marking the most significant reform to the structure of the developmental regime thus far(Gore et al., 2019). In combination with these reforms, the government's passage of the 2006 Strategic National Energy Policy (SNEP) signalled a change at the governance arrangements and policymaking levels from a purely developmental, state-led governance logic towards the layering of a market governance structure, albeit amidst the preservation of the developmental regimes function of expanding energy access(Kemausuor and Ackom, 2017).

The SNEP emphasized the importance of attracting private sector investment in generation, as well as the importance of creating incentives for investment in renewable energy production. The SNEP also directed the expansion of hydrocarbon energy supply through the completion of the West African Gas Pipeline (WAGP)(which enabled the import of natural gas from Nigeria) as well as intensified hydrocarbon exploration (Kemausuor and Ackom, 2017).

In 2009 John Atta Mills was inaugurated president, having defeated Kufour's NPP nominee Nana Akufo-Addo. Just as Kufour's government preserved the NES policy of grid expansion inherited from Rawlings, Mills' government did attempt to reassert government control over the increasingly liberalized generation sector. Liberalization had effectively split this responsibility onto multiple agents, both state-owned (the VRA) and private sector, and it was on this new hybrid power sector model that generation capacity would subsequently expand.

\section{The Unbalanced Growth of The Private Generation Industry}

The SNEP called for a sustainable development framework that aimed to attract private sector investment in both renewable and hydrocarbon based electricity production. The quasi-liberalization of the power sector did result in a significant expansion of private sector activity in electricity generation, however it was almost entirely concentrated in hydrocarbon based production (Aboagye et al., 2021). The unbalanced nature of this development is a reflection both of the state's prioritization of universal energy access over renewable energy development, and the way in which the layering of market governance during the Kufour administration's sector reforms created opportunities for strategic shirking on the part of ECG, the government's implementing agent.

In 2011 the Ghanian Parliament passed the Renewable Energy Act (REA), which amongst other things set a goal of $10 \%$ of electricity generation from renewable energy sources by 2020 (Kumi, 2017). While the goal of expanding electricity access thrived under a coherent, unified developmental regime for almost two decades, the goal of renewable energy development was conceived in a policy regime augmented by the implementation of liberalization reforms that lacked a similar coherence around this new policy goal. Misalignment between the administrative responsibilities and policy instruments of the Renewable Energy Act and the new layer of institutional incentives the liberalization reforms placed on the energy policy regime, in particular the solvency imperative com- 


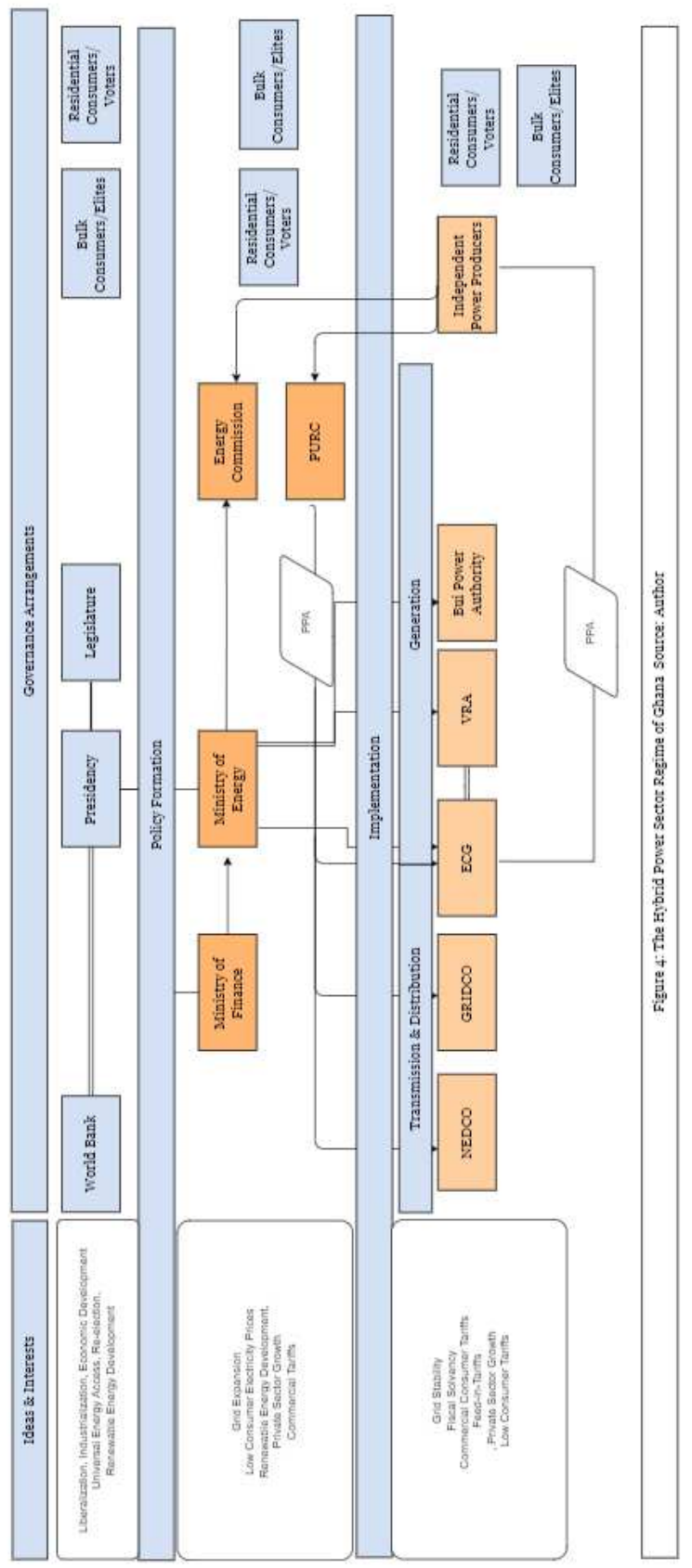

Figure 7: The Hybrid Policy Regime of Ghana 
mercialization placed on the major state-owned entities such as ECG and VRA, has frustrated efforts to grow renewable energy in the country.

The REA designated the Energy Commission as the pilot agency for the Act's implementation. That the Energy Commission, and not the Department of Mines and Energy, was chosen as the pilot agency for this policy goal reflected the choice at the governance arrangements not to incorporate renewable energy into the developmental regime apparatus responsible for industrialization and energy access, but under a mode of market governance (see figure 7). The EC was charged with overseeing the implementation of the three primary policy instruments designed to spur renewable energy generation: the Feed-In-Tariff and Net Metering Schemes and the Renewable Energy Fund.

\section{Feed In Tariff}

The Feed-In-Tariff (FiT) is a widely adopted policy in the developed world designed to incentivize IPPs by offering long-term, cost-reflective power purchase agreements (PPAs) that guarantee investors an acceptable rate of return. In Ghana, the FiT rate was to be set by the PURC in consultation with the EC based on the type of technology used to generate electricity, assurance of the financial integrity of public utilities, and a balancing of investor interest against the net effect of the cost of the renewable energy on consumer tariffs. The REA required both that the SOEs sign PPAs approved by the PURC under the FiT rate, and that they connect IPP's generation infrastructure to the transmission grid, the costs of which were to be passed to the IPP through the tariff rate (Kumi, 2017).

The FiT program initially attracted some investor interest, with the EC granting 124 provisional Wholesale Electricity Supply Licenses for utility scale gridconnected renewable energy (RE) projects in the years following the passage of the REA. However, of these 124 licensees only three projects have been commissioned. The failure to convert investor interest into electricity generation is generally attributed to breakdowns in the negotiations between IPPs, the PURC, and SOEs over the terms of PPAs. In particular, a central problem has been an underlying lack of confidence in ECGs willingness to honor payment obligations to renewable energy IPPs required under the REA, a reflection of ECG's obligation as an agent to its government principal's prioritization of electricity access. In the case of FiTs, as in the other policy instruments discussed in this section, ECG cited new institutional rules layered under commercialization in order to avoid shirk legislative obligations to develop renewable energy resources (Aboagye et al., 2021).

Net-Metering

The REA provided for the creation of the National Rooftop Solar Program, a net-metering scheme which would provide monetary incentives for residences 
to purchase solar panels and feed solar energy back into the grid. However, in 2017 when the program was to be scaled up following a successful pilot program, ECG raised financial concerns to the EC and PURC that the program would incur large revenue losses, bringing a halt to its implementation. While the EC and PURC have stated that they would work to reinstate the program, they have yet to come to an agreement with ECG and the NRSP remains on hold (Aboagye 2021).

\section{The Renewable Energy Fund}

The Renewable Energy Fund was created by the REA to "provide financial resources for the promotion, development, sustainable management and utilization of renewable energy sources." The problem with the Renewable Energy Fund is quite straightforward; it has never been significantly funded. While the REA outlined a variety of financing mechanisms, in practice, because the Renewable Energy Fund was under control of the Energy Commission, it was expected that the main source of funding would come from the EC's general Energy Fund. However, the Energy Fund itself is financed by a levy on petroleum products, which has provided only limited contributions, and thus the EC has not set part of the EF aside to support the REF (Aboagye et al., 2021).

\section{Exploitation of Ambiguities in a Layered Policy Regime}

The conclusion that ECG's refusal to honor its obligations to the FiT and Net-Metering programs is a selective exploitation of ambiguities created by the layering of commercialization rules is evidenced by the fiscal commitments the firm does make. In the period since the opening of the generation sector to private investment, the overwhelming majority of new generation capacity from the private sector has been from thermal sources (Aboagye et al., 2021)(Pueyo, 2018). Second, one of the primary sources of ECG's financial insolvency is a lack of revenue collection from government customers, which reflect $65 \%$ of the firm's rolling arrears (Pueyo, 2018). ECG's adherence to its solvency imperative is janus-faced; hawkish when it comes to meeting the costs of renewable energy policies, and dovish when it comes to meeting the obligations of the NES, funding private thermal generation, and holding government debtors accountable.

If there was any further doubt as to the policy regime's lack of commitment to the goal of renewable energy development, in 2017 the Energy Commission suspended the issuance of wholesale electricity generation licences to renewable energy IPPs. Ironically, the EC's reasoning was a problem of oversupply, which reflected the multi-year influx in generation from thermal-powered IPPs (Aboagye et al., 2021).

ECG's substantial investments in private thermal production and its subsidization of government electricity consumption reflect the continuing dominance of the central ideas, interests, and institutional relations of the developmental 
regime, in which a tightly knit coalition of state-owned enterprise management, ministry officials, and the office of the presidency maintain a cross-institutional, coherent focus on the expansion of electricity generation and distribution. The REA failed because it did not incorporate the goal of renewable energy growth into the structure of the developmental policy regime in the way that the National Electrification Scheme did. Because the growth of renewable energy in Ghana relies on cooperation from ECG, and ECG has both institutional incentives and legal rationales to shirk this cooperation, it is unlikely to be effective.

\subsection{Kenya}

Kenya leads Sub-Saharan Africa in renewable energy generation. However, until recently, Kenya lagged behind many of its peers in public access to electricity. The current state of the power sector reflects three important facts about its policy regime: 1) Kenya's regional leadership in renewable energy growth is a consequence of the incorporation of geothermal generation into the developmental regime's emphasis on industrialization. This initial incorporation has had path-dependent effects on the regime, which has increasingly relied on statecapital investment in geothermal energy to underwrite its ambitions for the power sector. 2) Kenya's recent successes in expanding electricity access are a consequence of two significant political-economic changes: heightened democratic pressures for public service delivery coming as a result of the legalization of multi-party democracy in 1992 placed pressures on the Kibaki government to invest in expanding access, changing ideas and interests at the governance arrangements level. However, the Kibaki government's progress on this issue was constrained by elements of regime incoherence introduced by the more robust implementation of liberalization reforms that had begun only half-heartedly under the previous Moi government. The return of the KANU to power in 2014 led to a reassertion of the central political-economic governance arrangements of the developmental regime, in which close coordination between KPLC and the KANU political leadership yielded swift progress towards government policies, with limited concern for the solvency of the public utility. Third, building on the two previous points, the introduction of liberalization reforms and market-based policy instruments have had only a marginal effect on either universal energy access or renewable energy growth. Progress towards both goals have come about when the developmental regime is functioning. Instead, the most significant effect of liberalization of Kenya's power sector has been the development of a private sector hydrocarbon generation industry.

State-Led Renewable Energy Growth In the mid 1970s, droughts affecting the reliability of installed hydroelectric capacity, projected increases in demand due to expanded industrial activity, and the volatile and increasing cost of importing oil for thermal generation (upon which the balance of Kenya's non-hydroelectric generation depended) all provided urgent incentives to ex- 
plore alternative energy sources. Geothermal exploration in Kenya had begun as early as 1956 with the drilling of two wells at Olkaria in the Rift Valley, and beginning in 1967, the Government of Kenya, in partnership with the United Nations Development Program, began extensive geothermal resource assessments, leading to a decision to focus further development on Olkaria. Six wells were drilled from 1971-1976, yielding positive results (MoEP 2013). However, it was not until 1978 that increasing oil prices made geothermal development cost competitive with thermal generation, and geothermal development began in earnest. The Development Plan of 1979-1983, financed largely by the World Bank, heavily prioritized geothermal, and 23 wells were drilled at Olkaria. The first geothermal power plant, Olkaria I, was commissioned in 1981, providing 45 MW of installed capacity. Olkaria II was subsequently completed by 1992 (World Bank, 1990)(Mwangi, 2005).

Private sector participation is responsible for a relatively small portion of Kenya's renewable energy generation. Instead, private sector investment has primarily contributed to the development of hydrocarbon based generationPueyo (2018)Godinho and Eberhard (2019). Not only has liberalization failed to spur renewable energy growth, but PPAs signed between the state and IPPs have been the target of credible allegations of corruption and overpricing. These allegations, as well as increases in power costs attributed to private sector tenders, led the Kenyatta government to cancel all ongoing and incomplete PPAs with IPPs.

Expansion of Electricity Access In contrast to the developmental regime of Ghana, socially-driven expansion of electricity access was not a priority at the governance arrangements level of the Kenyan power sector until the legalization of multi-party democracy in 1992 (Godinho and Eberhard, 2019). This placed pressure on the incumbent KANU government to expand service delivery, and thus a steady if slow expansion of electricity access began to take place in the 1990s. This period of expansion coincided with external pressures to reform the power sector from the centralized model that had persisted since decolonization, in which Kenya Power \& Lighting Co. (KPLC) occupied a central role as an implementing agent of government policy, maintaining close connections with key government decision makers (International Bank for Reconstruction and Development, 1967). In 1996 KPLC was unbundled into separate units for generation, transmission, and distribution, and the power sector was liberalized to encourage private sector participation(Newell and Phillips, 2016).

The increase in coordination costs across the power sector regime driven by the reforms is demonstrated by the ongoing conflict between KPLC (which maintained transmission and distribution responsibilities) and KenGen (the SOE developed to manage generation) in the early 2000s. In 2002 KPLC owed KenGen approximately $\$ 140$ million, and KenGen found itself unable to pay contractors on the ongoing Olkaria II geothermal project. A meeting between KPLC, KenGen, and the World Bank and European Investment Bank was held at the national treasury, bringing together stakeholders from all three levels of the pol- 


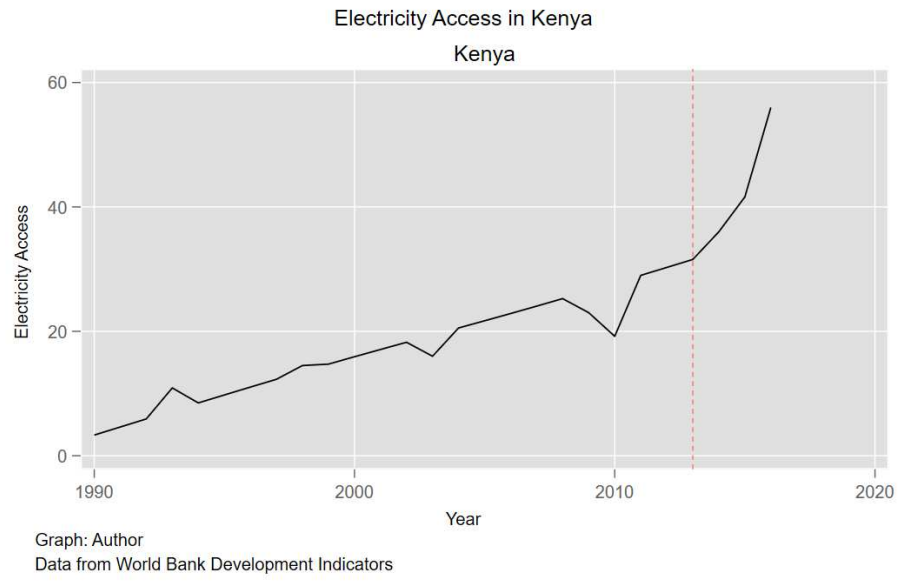

Figure 8: Electricity Access in Kenya 1990-2016

icy regime. Under pressure from funders, KPLC agreed to honor its debts to KenGen; it was now clear that it could no longer rely on the governance arrangement of the developmental regime. The government's interests remained concentrated in the expansion of generation, for which KPLC was no longer the established agent(Godinho and Eberhard, 2019).

Electricity access in the post-reform period grew at a slow if steady pace. More recently, however, Kenya has experienced rapid gains in electricity access and production. To what extent are these gains functions of the reforms? According to an independent analysis of the Kenyan power sector commissioned by the World Bank, recent gains in electricity generation and access have far more to do with state intervention in the sector than increases in private sector participation. In particular, the election of Uhuru Kenyatta and the return to power of the KANU appears to have resulted in something of a return to the sector's pre-reform developmental model, characterized by high levels of state spending in generation, transmission, and distribution, and a restoration of the KPLC's role as the implementing agent of state policy(Godinho and Eberhard, 2019). Figure 8 below charts the progression of electricity access during the reform period, with a notable increase in the rate of increase following the election of Kenyatta in 2013.

Kenya's modern power sector regime reflects a retreat away from the post-reform decentralization and towards a reconcentration of state power. Observers caution that this reassertion of so-called "political interference" in the power sector may augur inefficiencies in utility operations that bring down their fiscal sustainability and quality of service. However, the social gains to a more centralized power sector policy regime, in which KPLC and KenGen operate as clear agents 
of political principals, are undeniable. While reform efforts may have increased the creditworthiness of state-owned entities, the political sustainability of a liberalized power sector model is itself open to question, as millions of Kenyans continue to demand access to affordable electricity.

\subsection{South Africa}

South Africa is a regional leader in electricity access, but its performance in this regard has declined since the onset of a supply crisis that began in the mid-2000s. Its performance on renewable energy development, while lauded by many in the development community, is lacklustre in absolute terms and woeful relative to its potential. This study makes three regime-contingent points about the country's progress towards energy access and renewable energy development. The first is that regime incoherence emerging from the implementation of liberalization reforms is largely responsible for the supply crisis of the mid-2000s. Instead of maintaining the vertically-integrated, centralized power sector of the developmental period, the government signalled that the burden of generation would shift from the monopolistic SOE Eskom onto a non-existent private sector, leading to a generation shortage that still has yet to be filled. The second point is that the shortfall created by this incoherence presented ambiguities in the system that the Zuma administration exploited to build a vast patronage network that has had catastrophic effects on state capacity and legitimacy. This leads directly to the third point, which is that rather than being incorporated into the developmental regime, the introduction of renewable energy took place in the context of the Zuma administration's kleptocratic exploitation of ambiguities and incoherence wrought by the liberalization agenda. This has led to the paradoxical outcome that market-based policy instruments for the promotion of renewable energy have been an outright failure in the most developed market economy on the continent.

\section{Transition to Democracy, Introduction of Reforms, and the Expan- sion of Electricity Access}

Following the democratic transition, Nelson Mandela's African National Congress (ANC) government inherited a power sector that, while highly developed relative to others in the region, reflected the racist policies of the Apartheid regime. Organized around the vertically-integrated state-owned electricity giant Eskom, the power sector resembled other developmental sectors in the region in its centralization, and the proximity between management of the utility and the political apparatus that sat atop it. The ANC government faced immediate pressure both externally (from the World Bank) and internally (from liberation activists skeptical of all Apartheid-era institutions) to break up and overhaul Eskom. However, in recognition of Eskom's important role in supplying cheap energy to to what scholars call the Minerals-Energy-Complex (MEC) that lay 
at the heart of the national political economy, the ANC opted to maintain the firms' vertical-integration and thus political control over the power sector as a whole.

Retaining the centralized policy regime yielded immediate advantages in the early years of the Republic. The ANC moved swiftly to leverage its control over the sector to repair historic inequities in electricity access through the National Electrification Plan (NEP), an ambitious social electrification project which expanded the national grid in a genuine, non-racialized bid for universal electricity access. The NEP electrified 2.5 million new homes from 1994 to 2000, in a scheme organized around the developmental regime; the MoE financed the expansion (backed by international development financing), and Eskom implemented it.

In a parallel development, and following from the influence of IDIs at the governance arrangements level, the government acceeded to selective liberalization reforms over the course of the 1990s. In 1995, through Amendments to the Electricity Act of 1986, the Electricity Control Board was replaced with the National Energy Regulator of South Africa (NERSA), an independent regulator with far greater power than the ECB, including the ability to regulate market access through the licensing of all generation, transmission, and distribution firms, as well as tariff approval. The Eskom Amendment Act of 1998 vested ownership of the firms' equity in the state, repealed its tax-exempt status, and mandated that the Ministry of Public Enterprises incorporate Eskom as a limited liability corporation with share capital, opening the firm to equity financing on top of the state's controlling share. The Eskom Conversion Act of 2001 directed the firm to convert its generation, transmission, and distribution firms into three separate holding companies that were then slated for privatization. In the years leading up to and during these reforms, the government began denying Eskom's requests to finance additional generation capacity in anticipation of the firm's full privatization and the entry of IPPs into the market. Thus while the government maintained Eskom's centrality to the power sector, they corporatized its management structure and began the unbundling process(Greenberg, 2008).

\section{Reform and the Supply Crisis}

The portion of the reforms that most significantly impacted Eskom were the unbundling and subsequent privatization requirements dictated in the Conversion Act. Eskom began preparation for unbundling by organizationally "ringfencing" their generation, transmission, and distribution businesses, and readying assets for partial sale. However, by 2003, the government was already backing off from implementing privatization reforms; at the time, Finance Minister Trevor Manuel cited a poor global climate for privatization, as well as the recent California energy crisis which had come as a result of deregulation in the energy sector. After their 2004 election victory, the ANC formally announced that it would not be moving forward with the sale of Eskom's core assets. However, the 
initial reforms (in particular the halting of state investment in generation) had already had effects on the power sector, and this doubling back on implementation created a source of incoherence that would reverberate for over a decade. (Greenberg, 2008)

By 2004 Eskom's expansion of its generation capacity had been frozen for at least five years against rising national demand for electricity, propped up both by the NEP and significant economic growth. But by the time Eskom recommenced its program of expanding generation capacity in 2005, following the governments' announcement that it would remain public and "bundled," its resources were severely constrained, and low tariffs meant the firm had limited cash reserves. Whereas the general expectation was that by 2005 Eskom would be a partially privatized entity issuing shares for equity financing, instead it remained a fully public entity that was now raising capital through debt financing. Its obligations to serve the dual goals of social electrification and industrialization by providing cheap electricity remained the same, but were increasingly at odds with the institutional expectations and responsibilities layered by liberalization(Greenberg, 2008)(Bowman, 2020).

When Jacob Zuma came to power in 2009, South Africa was experiencing a full on electricity supply crisis, as private sector investment had failed to materialize sufficiently to fill the gap created by the state's withdrawal from the generation sector. The Zuma government's response was to foster generation supply through the economic channels of the Mbeki-era Black Economic Empowerment (BEE) initiative, in what was essentially a bid to create and indigenous, Black-owned private power generation sector. This strategy was reflected in Eskom's procurement budget, which rose from an annualized average of .8\% of GDP in the period 1998-2007 to over 3\% of GDP by 2012. Meanwhile, the newly appointed Minister of Public Enterprises made clear to Eskom management that it was no longer necessary to operate as a business, stating that this "is our money and we have the right to leverage it to achieve what we want to achieve." (Bowman, 2020)

Under Zuma, Eskom awarded billions of rand in tenders across the production, operation, and maintenance functions to many brand new firms that had emerged in the space created by BEE legislation. Unfortunately, many of these firms, led by politically-connected elites who have come to be known as tenderpreneurs, did not deliver on the terms of their contracts, resulting in construction failures and delays that stunted the recovery of the power sector(Bowman, 2020).

\section{Renewable Energy in the Hybrid Regime}

The exigencies of the energy crisis represented an important opportunity for the growth of renewable energy in South Africa. By 2008, renewable energy technologies were cost-competitive with fossil-fuels, and offered shorter lead times 
than did large, coal-fired power plants. In spite of their potential to help solve the crisis, however, renewables have not yet played a substantial role in repairing the energy shortfall, and by most indications, they are unlikely to anytime soon. Why has this been the case?

Eskom's role and strategy in resisting renewable energy development reflects two key characteristics of the hybrid power sector policy regime: 1) the set of interests at the governance arrangements level, which were now dominated by a combination of the MEC and the Zuma administration's buregoning parastatal patronage network, and 2) the ambiguity of responsibility created by the layering of commercialization rules.

\section{Tariff and Competition Suppression}

The government and the associated industries of the Minerals-Energy-Complex retain a shared interest in cheap electricity to power their respective political and economic goals. The coal industry has an interest in retaining Eskom's demand for its low grade coal assets with little export potential. Eskom can satisfy both of these interests through sub-commercial tariffs, which offer the dual benefit of providing cheap power to its principals and keeping the returns on investment sufficiently low so as to crowd out competition with coal from the renewables sector. Eskom is aided in doing so by the the labor unions and industry organizations which can pressure the government to hold tariffs in place. This relationship is demonstrated by a series of events in 2007 .

When NERSA (National Electricity Regulator of South Africa, the agency responsible for setting tarriff prices) approved a doubling of tariffs in 2007 to enable greater cost-recovery at Eskom, it was met with swift resistance from a combination of industry groups (Chamber of Mines, Minerals Council of South Africa, the EIUG) as well as trade unions. This led NERSA to slow the tariff increases, leading Eskom to pile on debt in order to continue providing electricity to its clients at sub-commercial rates. Meanwhile, Eskom's efforts to increase supply primarily focused on the troubled construction of the Medupi and Kusile coal-fired power plants, which have been slowed by a reliance on unreliable contractors from Zuma patronage network-Coal industry nexus(Bowman, 2020) (Burkhardt and Cohen, 2019).

Civil society protests against consumer tariff increases are now a regular element of South African politics. These reflect both the legitimate concern of South Africa's poor over the affordability of electricity, and the industrial lobby's preference for keeping electricity costs low.

\section{Exploitation of Commercialization}

Feed-in-Tariffs offer the opportunity for RE generation firms to side-step the government and MEC's downward pressure on tariffs by offering them guaranteed cost-recovery outside the generalized generation tariff structure. This policy in- 
strument breaks down, however, because it requires buy-in from Eskom, which must sign power purchase agreements (PPAs) in order to guarantee this cost recovery. Eskom is able to reject these PPAs because of ambiguities of responsibility created by the layering of commercialization rules. When pressured on its reluctance to sign PPAs, Eskom can cite its solvency and profitability obligations to shareholders. While Eskom's provision of cheap electricity to companies of the EIUG flies in the face of this solvency imperative, it can still be exploited in the interests of its principals at the governance arrangement level.

From the beginning of the energy shortfall in 2008, the Department of Energy issued calls for IPP bids to contribute to generation. Yet Eskom, which was responsible for concluding the bids by signing PPAs with the IPPs, consistently delayed key decisions that would have allowed IPPs cogeneration opportunities. This harmed both renewable and non-renewable contractors. 125 qualifying bids totalling $4900 \mathrm{MW}$ of generation capacity failed to obtain contracts with Eskom in this period (Ting and Byrne, 2020).

In 2009, the DOE amended the Electricity Regulation act to accommodate large-scale renewable energy projects with private sector investors, and NERSA began the Renewable Energy Feed-in Tariff (REFIT). However, NERSA was accused of stepping outside its mandate when it initiated legally binding tariff agreements ahead of Department of Energy approval. From 2009-11, the DOE and Treasury worked together to establish a framework for a competitive bidding process that would be called the Renewable Energy independent Power Producers Procurement Program (REI4P), which was launched in 2011 (along with the revocation of NERSA's Refit)(Ting and Byrne, 2020).

The development and implementation of REI4P has been applauded in that it was able to quickly generate interest and activity in renewable energy generation. Scholars have attributed this early success to the fact that RE I4P was developed and operated out of the IPP office within the DOE in close consultation with the Treasury Department, historically an institutional adversary of Eskom. The IPP office is an ad hoc group within DOE that is staffed by over one hundred private consultants with limited permanent staff from the government. According to interview evidence, the IPP office was able to work effectively with private sector partners to instill interest and confidence in the bidding process. Additionally, the RE I4P received significant attention in the public debate on the energy shortfall, leading to an open contestation of Eskom's dominance in the sector and enhanced public scrutiny on its behaviour. Leading up to 2015, South Africa produced approximately $5 \mathrm{GW}$ in four bidding windows across 77 Renewable energy generation projects (Ting and Byrne, 2020).

While RE I4P was able to make initial progress in securing bids, Eskom effectively resisted signing PPAs through a variety of subversive actions. In 2015, Eskom leveraged its monopoly status to block the signing of PPAs with RE I4PP IPPs by preventing them from receiving budget quotes necessary to fi- 
nalize their agreements. They also created additional barriers to entry by raising grid-connection costs for RE developers. Finally, Eskom encouraged the National Union of Metalworkers of South Africa (NUMSA) and the National Union of Mineworkers (NUM) to begin protesting the loss of jobs from the decommissioning of old coal-fired power plants. The NUM conducted nationwide strikes which halted the scheduled decommissioning of five old coal-fired power plants(Ting and Byrne, 2020). By 2017, under pressure from renewable energy industry associations and the press, NERSA began an investigation into Eskom's refusal to sign PPAs with renewable firms. When pressed on the matter, Energy Minister Mmamoloko Kubayi stated "Treasury issues guarantees to Eskom, and Eskom is concerned that if they are required to sign PPAs for REIPPP bid window 3.5, 4 and 5 projects, it will further impact negatively on their balance sheet. This is why we had to include Treasury to have a look at the impact to ensure we do not get another downgrade. We are waiting for the task team to come back to us." (Yelland, 2017). NERSA's investigation has itself been criticized for undue delays a reluctance to make hearings open to the public (Slabbert, 2017).

\subsection{Comparative Analysis}

A comparison of the Ghanaian, Kenyan, and South Africa experiences yields two important conclusions. The first is that when it comes to power sector policy goals, the most significant successes in electricity access and renewable energy growth have come when there are committed political principals at the governance arrangements level, and a limited set of agents at the policy formation and implementation levels whose primary interests lay with satisfying the demands of their principals. Ghana's success with the NES, South Africa's success with the NEP, and Kenya's successful geothermal development program all came under centralized power sector policy regimes in which tight networks bound implementing agents (a single, vertically integrated state-owned entity) to willing government principals who perceived the policy goal as an important political economic prerogative. Failure, on the other hand, has come when policy implementation is assigned to incoherent combinations of state and market actors with conflicting incentives and high coordination costs. Ghana's renewable energy development program has largely failed as it relies on coordination between implementing agents with split incentives (ECG's imperatives are to continue implementing the NES, and to reduce costs elsewhere). While South Africa's renewable energy development program REI4P saw initial success, it was ultimately halted when it came into conflict with the priorities of the state's primary implementation agent Eskom.

The second conclusion drawn from the comparison is that policy sequencing matters for implementation effectiveness. Ghana eventually began a serious implementation of liberalizing power sector reforms in 2005, but this was preceded 
by fifteen years of implementing state-led plans for universal energy access. By that time, a tight regime network between the government, the Ministry of Energy, and the Electricity Company of Ghana with shared sets of ideas about expanding electricity access had solidified around the goal and mode of governance behind the National Electrification Scheme. Evidence of ECG's pathdependent adherence to this regime goal is found in the company's declining fiscal position, which is a result of accumulated arrears from its two principal obligations: to provide power to government clients (which account for $65 \%$ of unpaid debt) and to the indigent beneficiaries of its electricity access program (Pueyo, 2018). On the other hand, the goal of renewable energy development was introduced into the policy regime after liberalization had begun in earnest, and ECG's corporatization and fiscal imperatives layered under liberalization reforms have served as a debilitating source of inconsistency with the goals and policy instruments of the market-led approach of the Energy Commission and private renewable energy generators. Further, instead of serving as a vehicle for renewable energy development, liberalization has resulted in the proliferation of private hydrocarbon production, which signs PPAs with ECG below the rate offered by Feed-in-Tariffs.

The importance of policy sequencing is evident in the Kenyan experience with renewable energy. While Kenya submitted to a robust implementation of power sector reforms around 2000, the introduction of geothermal generation decades earlier established renewable energy as a critical element of the developmental regime that was insulated against the impacts of reform. Instead, state-capital investment in geothermal generation remained a core element of the Kenyan power sector amidst pressure for widespread state divestment. The predominance of renewable energy as a priority at the governance arrangements level was affirmed through the creation of the Kenya Geothermal Corporation in 2008, which established a special purpose vehicle for retaining the relationship between presidential priorities, the Ministry of Energy, and the state-owned generation sector. More recently, the persistent effects of the developmental regime's understanding of renewable energy as a valuable investment of state capital has manifested in the Lake Turkana Wind Project, which resembles the developmental era approaches to geothermal in scale, financing structure, and government commitment. By contrast, private sector growth in the generation subsector, which has grown substantially since the implementation of liberalization reforms, has been overwhelmingly concentrated in hydrocarbon development.

The South African case illustrates the pitfalls of layering market logics on stateled policy regimes. While South Africa's power sector institutions and macroeconomic conditions positioned the nation to extend its generation capacity in the early 2000s, a truncated lurch towards privatization that removed generation from the state's portfolio left the country with an electricity shortfall that continues to plague it today. Efforts to shore up the country's generation capacity through private-sector partnership appear to have struggled amidst 
the ambiguities of responsibility created by sector liberalization; rather than continue to channel investment through Eskom, the bloating of the firm's procurement budget and its mandate to purchase from private firms has resulted in unfinished projects and financial waste. These shortcomings exhibit the coordination costs of splitting the generation responsibility between a single firm accountable to government principals and a diffuse network of IPPs that lack the same obligations as the state's implementing agent.

This comparison carries important lessons for policymakers concerned about renewable energy development in Sub-Saharan Africa. The legacy of develop-

mental regimes now coexists with a layered set of institutions from the era of power sector reform that are incentivized to expand private sector activity in electricity generation. But rather than lead to the growth of renewable energy, this expansion has been concentrated in hydrocarbon development. This particular growth trajectory is a consequence of the prevailing ideas of industrialization, economic development, and public service provision that bolster their political support at the governance arrangements level. The successful growth of renewable energy under a market-governance framework requires an alignment of the incentives of developmental regime institutions with the layered steering institutions introduced in the 2000s, such as the energy commission in Ghana. Such an alignment is unlikely, as neither their inherited political imperatives to their principals nor their layered commercial incentives lead them towards cooperation with steering agencies or legislative prerogatives. Instead, their political imperatives motivate them to focus capacities on expanding electricity access in ways that harm their fiscal health. This in turn provides a commercial rationale not to accept the costs of renewable energy PPAs proposed by the steering institutions, even in the face of legislative obligations to do so.

Forging coherence between developmental regime institutions and steering agencies in order to make market-based mechanisms work is unlikely so long as principals at the governance arrangements level prioritize industrialization and political support over renewable energy development. However, as demonstrated by the Kenyan case, when renewable energy is seen as an instrumental part of industrialization and the expansion of energy access, its incorporation into developmental policy regimes can result in rapid growth in renewables, but not through market-based mechanisms.

\section{Panel Data Analysis}

In order to conduct a broader test on the effects of liberalization reforms and market-based renewable energy development instruments on electricity access and production outcomes, I conducted a quantitative analysis of the effects of a set of policy interventions across twenty-two Sub-Saharan African countries over sixty years using a new panel-data set that combines previous data from the 
Power Sector Reform Tracker (Urpelainen and Yang, 2018), the World Bank Development Indicators, and new longitudinal data gathered by the author based on the Regulatory Indicators for Sustainable Energy (RISE 2020).

The goal of the analysis was to identify the relative strength of state-led and market-based policy instruments in promoting key power sector goals of universal energy access and renewable energy growth across a broad swath of SubSaharan African countries, accounting for differences in size, population, and democratic quality. The conclusions of the comparative case study suggested that a) state-led policy instruments tend to be more effective at promoting universal electricity access and renewable energy development, and b) that liberalization tends to decentralize policy regimes, increasing internal coordination costs and incoherence and detracting from policy implementation.

\subsection{Variables and Data}

The following is a description of the variables and measures used. A complete reporting of descriptive statistics can be found in Table 1.

\section{Dependent Variables}

Access to Electricity: A central motivation of power sector reform has been to increase access to electricity. In order to measure access to electricity, I use the Electricity Access (\% of Total Population) indicator from the World Bank's World Development Indicators data. The WDI data is available from 1990-2015.

Renewable Energy (\% of Total Electricity Production): Increasing electricity production from renewable energy relative to hydrocarbons is a key power sector priority both because it lowers dependence on costly imports of hydrocarbons used for thermal generation, increases the domestic security of supply, and reduces contributions to global warming.

\section{Independent Variables}

\section{Liberalization Reforms}

The liberalization reforms are a policy mix intended to make the power sector more efficient and productive and to attract private sector investment in generation by doing so. In order to measure the extent of power sector liberalization, I utilized data from the Power Sector Reform Tracker (PSRT) (Urpelainen and Yang, 2018) which tracks the implementation of specific power sector reforms at the country-year level from 1982-2013. The PSRT tracks eight key reform indicators based on country-level analysis of legislation and regulation. Each indicator is binary $(0,1)$ representing a yes/no indication of whether or not a reform has been implemented, and the PSRT score represents the sum total of 
these indicators (1-8). The use of a composite indicator is analytically desirable as these reforms are intended as a synergistic policy framework.

Liberalization Law: The passage of a law restructuring the power sector by unbundling, commercializing, and/or privatizing state-owned utilities and opening the sector to private investment and firms.

Corporatization: This variable indicates whether or not the state-owned entities have been corporatized, which means that they have been removed from the direct control of government and established as independent corporations with boards of directors.

Independent Regulatory Agency: The establishment of an independent regulatory control agency that sets electricity tariffs, issues licenses for private power sector activity, controls access to the transmissions network, and enforces sector regulations.

Independent Power Producers: This variable measures whether or not it is legal for independent power producers (IPPs) to operate in the generation subsector.

Unbundling: This variable indicates whether or not governments have divided vertically integrated SOEs into separate units for generation, transmission, and distribution. This reform is intended to remove natural monopolies and spur competition, leader to greater electricity supply.

Wholesale Electricity Markets: The creation of voluntary public wholesale electricity market institutions which allow suppliers to compete in the generation of electricity, guarantee access to the grid, and broker trades.

Choice of Supplier: The ability of consumers to select an electricity provider amongst multiple competitive providers.

Privatization: This variable indicates whether or not governments have privatized their state-owned entities by divesting and selling equity and assets to private sector investments, as well as submitting to organizational restructuring that outfits utilities as private corporations.

This work expects an inverse relationship between the implementation of liberalization reforms and the accomplishment of power sector goals. This expectation is based on the theoretical intuition that liberalization leads to decentralization, misaligned incentives, and administrative incoherence.

\section{Regulatory Indicators of Sustainable Energy (RISE)}

The World Bank has recently compiled a set of regulatory indicators it considers best practices for the development of sustainable energy and universal electricity access. The RISE indicators feature state-led and market-based policy instru- 
ments. This work has selected key indicators representing both state-led and market-based approaches to sustainable development.

National Electrification Plan (NEP): A National Electrification Plan is a governmentdesigned policy plan that outlines specific terms for implementation of on-grid and off-grid access to electricity. NEPs set time-based targets for national electrification rates and map out specific plans for completion based on particular grid extensions and investments in generation capacity as appropriate. They are state-led in that while they may include provisions to attract private sector investment, they feature clear state commitments of capital and institutional resources towards electrification.

National Renewable Energy Plan (NREP): A national renewable energy plan (NREP) is a government designed, state-led plan that includes renewable energy as part of generation planning, provides for state capital and institutional resources for renewable energy investment, and sets specific targets for implementation. NREPs go further than laws and policy frameworks for encouraging renewable energy investment and set out clear state-led strategies for increasing renewable energy as part of the national generation mix.

Feed-In-Tariff (FiT): Feed-in-Tariffs are a market-based instrument designed to induce investment in renewable energy generation by guaranteeing long term (10-20 year) cost-reflective tariff rates for independent power producers. FiTs reflect a delegation of renewable energy development implementation to private sector, rather than state-led actors.

This work expects NEPs and NREPs to be positively associated with growth in electricity access and renewable energy development, as they reflect a delegation of implementation to state institutions with clear responsibilities to principals. This is in contrast to FiTs, which rely on a combination of SOEs and Independent Power Producers with conflicting commercial incentives, as well as Independent Sector Regulators who face pressures to meet the demands of both. NEPs and NREPs feature clear obligations for SOEs as directed by political principals in the Ministry and/or Presidency, and are thus more likely to be effectively implemented by the state apparatus.

Data on RISE indicators is collected in the following way. The RISE website does not provide longitudinal data on the implementation of its selected regulations. Instead, RISE provides a recent "Scorecard" that ranks countries scores (0-100) on each indicator. RISE does not provide a year of implementation, but includes references to the legal documents (policy statements or legislation) that justify the scores. For each regulatory indicator (i.e. Feed-In-Tariff), a country is marked as " 1 " if the score is greater than 50 , and " 0 " if the score is less than 50. If the score is greater than 50, I identified the year of implementation using the documents provided by RISE. Year of implementation is used to create longitudinal data, with the value of implementation coded as "1" at the first year 
of implementation and held as " 1 " for every year thereafter. Country-years for each regulatory indicator prior to the year of implementation are coded as "0," representing the absence of the regulation.

\section{Control Variables}

GDP per Capita: National wealth is expected to have a positive impact on sector outcomes as it suggests greater availability of financial resources. I thus include GDP to control for variations in wealth. Data is from the World Bank World Development Indicators.

Democratic Quality: Competitive, pluralistic electoral democracies are expected to perform better than non-competitive, unipolar democracies in public service delivery, as governing parties face greater pressure to provide benefits to constituents in order to secure re-election. In order to measure democratic quality, I include the V-Dem Polyarchy index which assess the quality of electoral democracies around the world.

Land Area: For the models including electricity access, I include total land area (measured in sq. $\mathrm{km}$ ) as greater land area suggests greater difficulty in expanding electricity access into rural locations. Data is from the World Bank World Development Indicators.

Population: For the models including electricity access, I include population as a control as it should be more difficult for countries with higher populations to provide universal electricity access. Data is from the World Bank World Development Indicators.

\subsection{Models, Results, and Discussion}

Three panel regressions were run to estimate the effects of regulatory interventions on electricity access and renewable energy. Model (1) estimates the effects of the PSRI, NEPs, democratic quality, GDP, land area, and population on electricity access. Model (2) estimates the effect of PSRI, NREPs, democratic quality and GDP on renewable energy production as a share of total generation. Model (3) estimates the effects of PSRI, NREPs, Feed-in-Tariffs, democratic quality and GDP on renewable energy production as a share of total generation. Fixed-effects are employed in each model to account for unobserved effects at the country level. Clustered standard errors are employed to account for heteroskedasticity in the models. 
Table 1: Descriptive Statistics

\begin{tabular}{|c|c|c|c|c|c|c|c|}
\hline & \multicolumn{7}{|c|}{$(1)$} \\
\hline & count & sum & mean & $\mathrm{sd}$ & $\min$ & $\max$ & sum \\
\hline Electricity Access & 1296 & 37932.27 & 29.26872 & 25.80804 & .01 & 100 & 37932.27 \\
\hline Renewable Energy (\% of Total) & 957 & 1081.637 & 1.130237 & 3.925018 & 0 & 48.27479 & 1081.637 \\
\hline Power Sector Reform Index & 2928 & 1708 & .5833333 & 1.363749 & 0 & 8 & 1708 \\
\hline Electrification Plan & 505 & 215 & .4257426 & .4949454 & 0 & 1 & 215 \\
\hline Renewables Plan & 588 & 192 & .3265306 & .4693432 & 0 & 1 & 192 \\
\hline Democratic Quality & 2673 & 786.681 & .2943064 & .1970051 & .009 & .84 & 786.681 \\
\hline GDP (current USD) & 2498 & $3.33 \mathrm{e}+13$ & $1.33 \mathrm{e}+10$ & $4.45 \mathrm{e}+10$ & 9122751 & $5.47 \mathrm{e}+11$ & $3.33 \mathrm{e}+13$ \\
\hline Population & 2919 & $3.44 \mathrm{e}+10$ & $1.18 \mathrm{e}+07$ & $2.03 \mathrm{e}+07$ & 41700 & $2.06 \mathrm{e}+08$ & $3.44 \mathrm{e}+10$ \\
\hline Land & 2734 & $1.38 \mathrm{e}+09$ & 505160.5 & 566157.2 & 460 & 2481353 & $1.38 \mathrm{e}+09$ \\
\hline$N$ & 2928 & & & & & & \\
\hline
\end{tabular}


Table 2: Panel Regression Results

\begin{tabular}{|c|c|c|c|}
\hline & $\begin{array}{c}(1) \\
\text { Elec. Access (\% of Pop.) }\end{array}$ & $\begin{array}{c}(2) \\
\text { Renewable Energy Prod. (\% of Total) }\end{array}$ & $\begin{array}{c}(3) \\
\text { Renewable Energy Prod. (\% of Total) }\end{array}$ \\
\hline PSRI & $\begin{array}{c}-0.456^{* *} \\
(-2.91)\end{array}$ & $\begin{array}{c}0.0380 \\
(0.97)\end{array}$ & $\begin{array}{c}0.0410 \\
(1.06)\end{array}$ \\
\hline National Electrification Plan & $\begin{array}{c}4.064^{* * *} \\
(4.90)\end{array}$ & & \\
\hline Democratic Quality & $\begin{array}{c}13.23^{* *} \\
(2.75)\end{array}$ & $\begin{array}{l}1.636 \\
(1.11)\end{array}$ & $\begin{array}{l}1.365 \\
(0.93)\end{array}$ \\
\hline GDP (current USD) & $\begin{array}{c}-1.30 \mathrm{e}-11 \\
(-1.42)\end{array}$ & $\begin{array}{c}-1.44 \mathrm{e}-12 \\
(-1.00)\end{array}$ & $\begin{array}{l}-3.97 \mathrm{e}-13 \\
(-0.26)\end{array}$ \\
\hline Land Area (sq. km) & $\begin{array}{l}0.000000812 \\
\quad(0.22)\end{array}$ & & \\
\hline Population & $\begin{array}{l}0.000000469^{* * *} \\
(6.78)\end{array}$ & & \\
\hline National Renewable Energy Plan & & $\begin{array}{l}1.000^{* * *} \\
(5.41)\end{array}$ & $\begin{array}{l}1.190^{* * *} \\
(5.90)\end{array}$ \\
\hline Feed-in-Tariff & & & $\begin{array}{l}-0.975^{*} \\
(-2.27)\end{array}$ \\
\hline _cons & $\begin{array}{r}6.810 \\
(1.78) \\
\end{array}$ & $\begin{array}{l}-0.352 \\
(-0.55) \\
\end{array}$ & $\begin{array}{l}-0.297 \\
(-0.47) \\
\end{array}$ \\
\hline$N$ & 384 & 272 & 272 \\
\hline
\end{tabular}

$t$ statistics in parenthese

${ }^{*} p<0.05,{ }^{* *} p<0.01,{ }^{* * *} p<0.001$ 


\section{Results \& Discussion}

The existence of a national electrification plan demonstrates a strong (4\%) and statistically significant impact on electricity access. By contrast, the implementation of liberalization reforms demonstrates an inverse, statistically significant relationship with electricity access. While the effect of a unit-increase is not particularly strong $(-.45 \%)$, it should be noted that this is a continuous variable reflecting the increasing implementation of liberalization on a scale from $1-8$. Thus a full implementation would suggest a $3.6 \%$ decrease in access to electricity. This suggests that strong state-planning for national electrification contributes positively to expanding electricity access, while attempting to reform the sector through measures that liberalize and decentralize authority in the sector are associated with lower levels of access.

The existence of a national renewable energy plan demonstrates a small (1\%) but significant effect on the renewable energy production as a portion of total electricity generation. This effect is slightly (.190) stronger when run in a model alongside Feed-in-Tariffs, which exhibits weak, mildly negative effects on renewable energy as a portion of total production. While this does not provide strong evidence in support of state-led planning for renewable energy development, it does not offer support for market-based strategies either.

\section{Conclusion}

This work argues that policy regime coherence, or the alignment of ideas and interests between and across actors at the governance arrangements, policy formation, and policy implementation levels, is essential for the successful actualization of ambitious policy goals. The comparative case study of three African power sectors over the sixty years since independence demonstrated the important role of regime coherence in effective policy implementation. In all three cases it is clear that state-led policies that emphasize direct investment of public capital and resources are instrumental to accomplishing these goals. It is also clear that these states' power sectors performed at their best under centralized, coherent policy regimes that retain aligned incentives between government principals and bureaucratic agents. While market-based mechanisms have attracted some investment in generation in all three cases, these do not appear to have benefited electricity access or renewable energy development, and it is far from clear that they have led to either cost reductions or gains in efficiency, as they frequently resulted in cost-overruns and allegations of corruption in procurement.

This work further investigated the thesis of coherence through a quantitative analysis using original panel data on regulatory interventions. Coefficient estimates from the panel data provided modest support for the effectiveness of 
state-led policy planning in increasing electricity access. Consistent with both theoretical expectations and inductive intuitions from the case study, liberalization reforms that reassigned implementation responsibilities from the state to the market were negatively associated with progress towards electricity access. Weaker support was found for the role of state-led planning in renewable energy development, however market-based mechanisms did not find support either. State-led renewable energy generation plans are generally less common and more recent as the incorporation of the sustainable development goal has primarily taken place in post-liberalization policy regime settings wherein the role of the state in the power sector has been reconceptualized. Future research should closely examine the comparative success of state vs. market-led approaches in renewable energy growth, accounting for how variations in policy regimes impact the success of both.

Endemic to the study of Africa's energy problems is a focus on providing stable policy frameworks to attract private investment into the sector. This literature's assumption of the role of African states as facilitators of capital has detracted from examining their role as active builders of their own energy futures. The results of this work suggest that a renewed focus on the role and possibilities of the state is justified. Further, as scholars continue to affirm the importance of institutional quality for economic development, greater attention should be paid to how the specifics of public sector organization contribute to this variable. Ghana and Kenya have both variously been portrayed as victories of marketled approaches to development, hailed as strong investment environments with relatively stable democratic governments. These characterizations belie the role that periods of dedicated, centralized public sector organization have played in each country's respective successes in the power sector.

Advocates of the FIG approach will likely respond that this work's argument assumes a level of state-capital that simply does not exist, and that the focus on attracting private investment is thus a financial necessity for realizing either renewable energy development or universal electricity access. However, the successes of the developmental regimes in the comparative case study were financially contingent on sources of concessionary finance from the World Bank, the UNDP, USAID, and other bilateral lenders, flows from which are now at their highest levels in history (Gill 2018). Rather than any fundamentally financial difference, the fact that large-scale, state-led, donor funded investment in renewable energy and grid expansion are now the exception rather than the norm seems more clearly a product of the distinct policy frameworks African democracies found themselves forced to accept as they emerged from the civil and economic tumult of the 1980s. Ghana's National Electrification Scheme, South Africa's National Electrification Plan, and Kenya's state-led development of geothermal resources are the hallmarks of their respective policy successes, and they have far more to do with preserving elements of their developmental regimes than with private sector participation. 
While Western development institutions continue to converge around a model of sustainable development for Africa that shares the assumptions of the financial investment governance perspective, China has emerged as the major new development partner on the continent. When one reflects on how China approaches development in Africa in light of the hybrid regime structure that characterizes most power sectors on the continent, it is unsurprising that the majority of African countries now vote with China on U.N. resolutions. Much of this has been attributed to the way in which China's policy of non-conditionality of assistance offers an alternative to Western pressures for democratic and human rights reform. But with regard to the power sector, what is perhaps equally important is the fact that Chinese development assistance both fits better with and places no further reformatory pressures on the developmental policy regimes that have traditionally worked in Africa. China has repeatedly demonstrated a willingness to directly finance and aid in the construction of large-scale generation, transmission, and distribution projects as part of its global Belt-and-Road initiative (IEA 2016). Future scholarship might explore the ways in which China's development approach represents a "back to the future" effect that offers unique institutional compliments to the historical policy regime structures.

\section{References}

Bernard Aboagye, Samuel Gyamfi, Eric Antwi Ofosu, and Sinisa Djordjevic. Status of renewable energy resources for electricity supply in Ghana . Scientific African, 11, 2021. doi: https://doi.org/10.1016/j.sciaf.2020.e00660.

Daron Acemoglu and James A Robinson. Why Nations Fail: The Origins of Power, Prosperity and Poverty. Crown, New York, NY, 2012.

Helene Ahlborg, Frida Borang, Sverker C. Jagers, and Patrik Söderholm. Provision of electricity to African households: The importance of democracy and institutional quality . Energy Policy, 87:125-135, 2015. doi: https://doi.org/10.1016/j.enpol.2015.09.002.

Michael Aklin and Johannes Urpelainen. Renewables: The Politics of a Global Energy Transition. MIT Press, Cambridge, MA, 2018.

Michaël Aklin and Johannes Urpelainen. Political Competition, Path Dependence, and the Strategy of Sustainable Energy Transitions . American Journal of Political Science, 57.

Michaël Aklin, Patrick Bayer, S. P. Harish, and Johannes Urpelainen. Escaping the Energy Poverty Trap: When and How Governments Power the Lives of the Poor. MIT Press, Cambridge, MA, 2018.

Philip Andrews-Speed. Applying institutional theory to the low-carbon energy transition . Energy Research Social Science, 13:216-225, 2016. doi: https://doi.org/10.1016/j.erss.2015.12.011. 
Lucy Baker and Benjamin K. Sovacool. The political economy of technological capabilities and global production networks in South Africa's wind and solar photovoltaic (PV) industries . Political Geography, 60:1-12, 2017. doi: https://doi.org/10.1016/j.polgeo.2017.03.003.

Lucy Baker, Peter Newell, and Jon Phillips. The Political Economy of Energy Transitions: The Case of South Africa . New Political Economy, 19:791-818, 2014. doi: https://doi.org/10.1080/13563467.2013.849674.

Robert H. Bates. When Things Fell Apart: State Failure in Late-Century Africa. Cambridge, Cambridge, Massachusetts, 2012.

F. Baumgartner and B. Jones. Agendas and Instability in American Politics. University of Chicago Press, Chicago, IL, 1993.

Andrew Bowman. Parastatals and economic transformation in South Africa: The political economy of the Eskom crisis . African Affairs, 119:395-431, 2020. doi: https://doi.org/10.1093/afraf/adaa013.

Paul Burkhardt and Michael Cohen. How Medupi and Kusile are sinking South Africa, 2019.

Aleh Cherp, Vadim Vinichenko, Jessica Jewell, Elina Brutschin, and Benjamin Sovacool. Integrating technoeconomic, sociotechnical and political perspectives on national energy transitions: A metatheoretical framework . Energy Research Social Science, 37:175-190, 2017. doi: http://sro.sussex.ac.uk/id/eprint/70345/4/1-s2.0-S2214629617302815main.pdf.

Paul Collier and Anthony Venables. Greening Africa? Technologies, endowments and the latecomer effect . Energy Policy, 102:52-72, 2017. doi: https://doi.org/10.1016/j.enpol.2016.12.008.

Taryn Dinkelman. The Effects of Rural Electrification on Employment: New Evidence from South Africa . American Economic Review, 101:3078-3108, 2011. doi: 10.1257/aer.101.7.3078.

Jennifer A. Elliot. An Introduction to Sustainable Development. Routledge, UK, 2012.

Ben Fine and Zavareh Rustomjee. The Political Economy of South Africa. Westview Press, 1996.

Vivien Foster and Anshul Rana. Rethinking Power Sector Reform in the Developing World, 2020.

Frank Geels. Technological transitions as evolutionary reconfiguration processes: a multi-level perspective and a case-study . Research Policy, 31:1257-1274, 2002. doi: https://doi.org/10.1016/S0048-7333(02)00062-8. 
Frank Geels. The multi-level perspective on sustainability transitions: Responses to seven criticisms . Environmental Innovation and Societal Transitions, 1:1-21, 2011. doi: https://doi.org/10.1016/j.eist.2011.02.002.

Frank W. Geels and Johan Schot. Typology of sociotechnical transition pathways . Research Policy, 36:399-417, $2007 . \quad$ doi: https://doi.org/10.1016/j.respol.2007.01.003.

Audley Genus and Anne-Marie Coles. Rethinking the multi-level perspective of technological transitions . Research Policy, 37:1436-1445, 2008. doi: 10.1016/j.respol.2008.05.006.

Catrina Godinho and Anton Eberhard. Learning From Power Sector Reform: The Case of Kenya, 2019.

Christopher D. Gore, Jennifer N. Brass, Elizabeth Baldwin, and Lauren M. MacLean. Political autonomy and resistance in electricity sector liberalization in Africa. World Development, 120:193-209, $2019 . \quad$ doi: https://doi.org/10.1016/j.worlddev.2018.03.003.

Government of Ghana. Energy Commission Act 1997, 1997.

Katherine N. Gratwick and Anton Eberhard. Demise of the standard model for power sector reform and the emergence of hybrid power markets . Energy Policy, 36(10):3948-3960, 2008. doi: https://doi.org/10.1016/j.enpol.2008.07.021.

Stephen Greenberg. 'Market liberalization and continental expansion: The repositioniing of Eskom in post-apartheid South Africa' in 'Electric Capitalism: Recolonising Africa on the Power Grid' David A. McDonald, ed. HSRC Press, 2008.

Julian Gregory and Benjamin K. Sovacool. Rethinking the governance of energy poverty in sub-Saharan Africa: Reviewing three academic perspectives on electricity infrastructure investment . Renewable and Sustainable Energy Reviews, 2019. doi: https://doi.org/10.1016/j.rser.2019.05.021.

Michael Howlett. Governance modes, policy regimes, and operational plans: A multi-level nested model of policy instrument choice an policy design . Policy Sciences, 42:73-89, 2009. doi: 10.1007/s11077-009-9079-1.

IEA. World Energy Outlook 2020, 2020.

International Bank for Reconstruction and Development. Prospects for Economic Development in East Africa: Volume II - Kenya Part Six Annex E Electric Power, 1967.

International Bank for Reconstruction and Development. Appraisal of the Distribution Expansion and Development Program of the Electricity Corporation of Ghana, 1968. 
International Bank for Reconstruction and Development. The Current Economic Position and Prospects of Ghana: Volume X Summary and Conclusions, 1970.

Chalmers Johnson. MITI and the Japanese Miracle: The Growth of Industrial Policy 1925-1975. Stanford University Press, Stanford, 1982.

Francis Kemausuor and Emmanuel Ackom. Toward universal electrification in Ghana . WIREs Energy Environ, 6:225, 2017. doi: 10.1002/wene.225.

Florian Kern and Michael Howlett. Implementing Transition Management as Policy Reforms: A Case Study of the Dutch Energy Sector . Policy Sciences, 42, 2009. doi: https://doi.org/10.1007/s11077-009-9099-x.

Shahidur R. Khandker, Douglas F. Barnes, and Hussain A. Samad. The Welfare Impacts of Rural Electrification in Bangladesh . The Energy Journal, 33:187206, 2012. doi: 10.5547/ISSN0195-6574-EJ-Vol33-No1-7.

Ebenezer Nyarko Kumi. The Electricity Situation in Ghana: Challenges and Opportunities, 2017.

Mercè Labordena, Anthony Patt, Morgan Bazilian, Mark Howells, and Johan Lilliestam. Impact of political and economic barriers for concentrating solar power in Sub-Saharan Africa . Energy Policy, 102:52-72, 2017. doi: https://doi.org/10.1016/j.enpol.2016.12.008.

M Lawhon and J.T. Murphy. Socio-technical Regimes and Sustainability Transitions: Insights from Political Ecology . Progress in Human Geography, 36: 354-78, 2011. doi: 10.1177/0309132511427960.

Adrian Leftwich. Bringing politics back in: Towards a model of the developmental state . The Journal of Development Studies, 31:400-427, 1995. doi: $10.1080 / 00220389508422370$.

J. Mahoney and K. Thelen. Explaining Institutional Change: Ambiguity, Agency and Power. Cambridge University Press, Cambridge, UK, 2010.

Peter May. Implementation failures revisited: Policy regime perspectives . Public Policy and Administration, 30, 2015. doi: 10.1177/0952076714561505.

Peter J May and Ashley E Jochim. Policy regime perspectives: Policies, politics, and governing. Policy Studies Journal, 41(3):426-452, 2013.

J. Meadowcroft. Engaging with the Politics of Sustainability Transitions', Environmental Innovation and Societal Transitions . Environmental Innovation and Societal Transitions, 1:70-75, 2011. doi: https://doi.org/10.1016/j.eist.2011.02.003.

Stephan F. Miescher. Nkrumah's Baby": the Akosombo Dam and the dream of development in Ghana, 1952-1966 . Water History, 6:341-366, 2014. doi: https://doi.org/10.1007/s12685-014-0112-8. 
Martin N. Mwangi. Phases of Geothermal Development in Kenya, 2005.

Peter Newell and Jon Phillips. Neoliberal energy transitions in the South: Kenyan experiences . Geoforum, 74:39-48, $2016 . \quad$ doi: http://sro.sussex.ac.uk/id/eprint/66473/.

Ana Pueyo. What constrains renewable energy investment in Sub-Saharan Africa? A comparison of Kenya and Ghana . World Development, 109:85-100, 2018. doi: https://doi.org/10.1016/j.worlddev.2018.04.008.

REN21. Renewable Global Status Report, 2018.

A. Rip and R. Kemp. Technological change. Batelle Press, Columbus, OH, 1998.

Antoinette Slabbert. 11 months later, Nersa postpones IPP investigation, 2017.

Christoph Stefes and Frank N Laird. Creating Path Dependency: The Divergence of German and U.S. Renewable Energy Policy . APSA 2010 Annual Meeting Paper, 2010. doi: https://papers.ssrn.com/sol3/papers.cfm?abstract ${ }_{i} d=1644532$.

Marie Blanche Ting and Rob Byrne. Eskom and the rise of renewables: regimeresistance, crisis and the strategy of incumbency in South Africa's electricity system . Energy Research and Social Science, 60, 2020. doi: http://sro.sussex.ac.uk/id/eprint/90029/.

Johannes Urpelainen and Joonseok Yang. Global Patterns of Power Sector Reform, 1982-2013 . Energy Strategy Reviews, 2018. doi: https://ssrn.com/abstract $=3301148$.

John Urry. Climate Change and Society. Wiley, New York, NY, 2011.

Thijs Van de Graad, Benjamin K. Sovacool, Arunabha Ghosh, Florian Kern, and Michael T. Klare. The Palgrave Handbook of the International Political Economy of Energy. Palgrave, UK, 2016.

World Bank. Project Completion Report- Republic of Kenya- The Olkaria Geothermal Engineering Project, The Olkaria Geothermal Power Project, The Olkaria Geothermal Power Expansion Project, 1990.

World Bank. Project Completion Report: Northern Grid Extension Project Credit 1759-GH, 1993.

Chris Yelland. Op-Ed: No end in sight to Eskom delays in signing renewable energy PPAs, 2017. 